\title{
Biochemical and functional properties of mammalian bone alkaline phosphatase
}

\section{isoforms during osteogenesis}

\author{
Cecilia Halling Linder
}

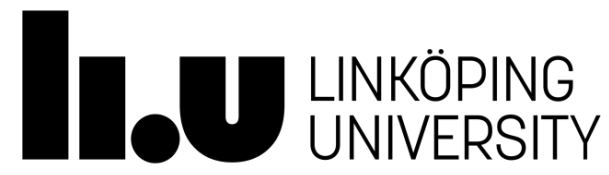

\footnotetext{
Department of Clinical and Experimental Medicine

Faculty of Medicine and Health Sciences

Linköping University

58185 Linköping, Sweden
} 
Cover: Human osteoblasts (hFOB 1.19). Photo by Lars Faxälv/Cecilia Halling Linder

(C) Cecilia Halling Linder, 2016

cecilia.halling.linder@regionostergotland.se

Published articles included in this thesis have been reprinted with the permission of the respective copyright holders.

Printed in Sweden by LiU-Tryck, Linköping, Sweden, 2016

ISBN: 978-91-7685-824-0

ISSN: 0345-0082 


\section{"Failure is not an option"}

Gene Kranz,

NASA Flight Director

Gemini \& Apollo Missions

Dedicated to Ingvar Linder 


\section{SUPERVISOR}

Per Magnusson, Adj Professor

Department of Clinical and Experimental Medicine

Linköping University

CO-SUPERVISOR

Elvar Theodorsson, Professor

Department of Clinical and Experimental Medicine

Linköping University

CO-SUPERVISOR

Göran Andersson, Professor

Department of Laboratory Medicine

Karolinska Institutet

\section{OPPONENT}

Torgny Stigbrand, Professor Emeritus

Department of Clinical Microbiology

Umeå University 


\section{ABSTRACT}

The human skeleton is a living and dynamic tissue that constantly is being renewed in a process called bone remodeling. Old bone is resorbed by osteoclasts and new bone is formed by osteoblasts. Bone is a composite material made up by mineral crystals in the form of hydroxyapatite (calcium and phosphate) that provides the hardness of bone, and collagen fibrils that provides elasticity and flexibility. Alkaline phosphatase (ALP) is a family of enzymes that is present in most species and catalyzes the hydrolysis of various phosphomonoesters at alkaline $\mathrm{pH}$. Despite the generalized use of ALP as a biochemical marker of bone formation, the precise function of bone ALP (BALP) is only now becoming clear. Three circulating human BALP isoforms (B1, B2, and B/I) can be distinguished in healthy individuals and a fourth isoform (B1x) has been discovered in patients with chronic kidney disease and in bone tissue.

Paper I. Three endogenous phosphocompounds, (i.e., inorganic pyrophosphate (PPi), pyridoxal 5'-phosphate (PLP) and phosphoethanolamine (PEA)), have been suggested to serve as physiological substrates for BALP. The BALP isoforms display different catalytic properties towards PPi and PLP, which is attributed to their distinct N-linked glycosylation patterns. The catalytic activity, using PEA as substrate, was barely detectable for all BALP isoforms indicating that PEA is not a physiological substrate for BALP.

Paper II. Mouse serum ALP is frequently measured and interpreted in mammalian bone research. However, little is known about the circulating ALPs in mice and their relation to human ALP. We characterized the circulating and tissue-derived mouse ALP isozymes and isoforms from mixed strains of wild-type and knockout mice. All four BALP isoforms (B/I, B1x, B1, and B2) were identified in mouse serum and bone tissues, in good correspondence with those found in human bones. All mouse tissues, except liver, contained significant ALP activities. This is a notable difference as human liver contains vast amounts of ALP.

Paper III. The objective of this study was to investigate the binding properties of human collagen type I to human BALP, including the two BALP isoforms B1 and B2, together with ALP from human liver, human placenta and E. coli. A surface plasmon resonance-based analysis showed that BALP binds stronger to collagen type I in comparison with ALPs expressed in non-mineralizing tissues. The B2 isoform binds significantly stronger to collagen 
type I in comparison with the B1 isoform, indicating that glycosylation differences in human ALPs are of crucial importance for protein-protein interactions with collagen type I.

Paper IV. Tartrate-resistant acid phosphatase (TRAP) is highly expressed in osteoclasts and frequently used as a marker of bone resorption. Intriguingly, recent studies show that TRAP is also expressed in osteoblasts and osteocytes. TRAP displays enzymatic activity towards the endogenous substrates for BALP, i.e., PPi and PLP. Both TRAP and BALP can alleviate the inhibitory effect of osteopontin on mineralization by dephosphorylation, which suggests a novel role for TRAP in skeletal mineralization. 


\section{POPULÄRVETENSKAPLIG SAMMANFATTNING}

\section{Benspecifikt alkaliskt fosfatas - biokemiska och funktionella egenskaper}

Skelettet är nödvändigt för kroppens rörelseförmåga och hållfasthet. Det pågår ständigt en förnyelse av skelettet och ca $10 \%$ förnyas per år hos vuxna. Det sker genom att gammal och defekt benvävnad bryts ner av celler i benvävnaden, osteoklaster, och att ny benvävnad byggs upp av osteoblaster. Benvävnaden består till $70 \%$ av mineral, huvudsakligen kalcium och fosfat i form av hydroxiapatit, som ger skelettet dess hårdhet. Resterande $30 \%$ består av organiskt material, framför allt kollagen typ I, som ger skelettet dess flexibilitet.

Alkaliskt fosfatas (ALP) finns i alla arter, organ och vävnader. Benspecifikt ALP (BALP) är ett enzym som har en central roll i mineraliseringen av skelettet. Mutationer i BALP-genen ger den ärftliga sjukdomen hypofosfatasi som kännetecknas av defekt mineralisering av skelettet. I serum från friska individer återfinns tre olika former av BALP, så kallade isoformer, benämnda B/I, B1 och B2. En fjärde isoform, B1x, har hittats hos patienter med kronisk njursjukdom och i benvävnad. Alla isoformerna har samma grundstruktur och skillnaden mellan dessa isoformer beror på molekylära modifieringar så som kolhydrater (glykosyleringar) på proteinstrukturen.

Trots en utbredd användning av BALP som en biokemisk markör för benformation är dess funktion inte helt kartlagd. Våra arbeten har strävat mot att öka kunskapen om de olika isoformernas funktion och varför de återfinns på olika platser i skelettet.

Hos patienter med hypofosfatasi ansamlas stora mängder av oorganiskt pyrofosfat (PPi), pyridoxal-5'-fosfat (PLP) och fosfoetanolamin (PEA) och dessa tre ämnen tros vara naturliga substrat för BALP. Vi har studerat hur snabbt de olika BALP-isoformerna omvandlar dessa substrat till fritt fosfat som används vid bildandet av hydroxiapatit. Även två rekombinanta former av ALP har studerats, TNALP-flag och sALP-FcD 10 som är ett potentiellt läkemedel för behandling av hypofosfatasi. Isoformen B2 uppvisade signifikant högre enzymatisk aktivitet för PPi och PLP jämfört med de andra isoformerna och de två rekombinanta formerna av ALP hade liknande aktivitet som de humana isoformerna. Ingen av de studerade formerna uppvisade någon aktivitet för PEA, och baserat på detta förkastas hypotesen att PEA är ett substrat för BALP. Skillnaden mellan isoformernas aktivitet beror på skillnader i deras kolhydrater. Dessa kolhydrater påverkar även inbindningen till det organiska materialet kollagen typ I i skelettet. Endast BALP av alla ALP former binder starkt till kollagen och isoformen $\mathrm{B} 2$ binder in dubbelt så starkt jämfört med B1. Slutsatsen av våra resultat är att det finns mer B2 i benvävnad med hög benomsättning för att snabbt producera fritt fosfat som är en av byggstenarna i hydroxiapatit. B1 återfinns i högre grad i ben med låg benomsättning där det inte behöver produceras lika mycket fosfat.

Möss används ofta som djurmodeller vid experimentell forskning. Det är dock lite känt om de olika ALP formerna hos möss och deras relation till humant ALP. Resultaten visade att möss har identiska BALP-isoformer som människa och att alla studerade musvävnader utom 
lever innehåller betydande mängder ALP. Detta skiljer sig från den mänskliga levern som innehåller stora mängder ALP, vilket måste beaktas då ALP analyseras och tolkas vid djurexperimentella försök.

Osteopontin (OPN) är viktigt för regleringen när hydroxiapatit bildas under mineraliseringsprocessen. Fosforylerat OPN hämmar bildandet av hydroxiapatit och graden av fosforylering är avgörande för dess hämmande effekt. Tartrat-resistent surt fosfatas (TRAP) utsöndras i huvudsak från osteoklaster men även från osteoblaster och osteocyter. TRAPs funktion i mineraliseringsprocessen har inte tidigare studerats. Våra resultat visar hur BALP och TRAP reglerar mineraliseringen genom defosforylering av OPN. Dessa resultat visar att även TRAP skulle kunna ha en reglerande funktion vid mineraliseringen av skelettet.

Resultaten från våra studier ökar förståelsen för hur mineraliseringen av skelettet regleras. Flera komponenter medverkar till en normal mineralisering och våra resultat visar hur de olika BALP isoformerna samverkar med andra molekyler för att påverka mineraliseringen på olika sätt. 


\section{LIST OF PAPERS}

This thesis is based on the following papers, which will be referred to in the text by their Roman numerals (I-IV):

I

Halling Linder C, Narisawa S, Millán JL, Magnusson P.

Glycosylation differences contribute to distinct catalytic properties among bone alkaline phosphatase isoforms.

Bone 2009;24: 987-993.

II Halling Linder C, Englund UH, Narisawa S, Millán JL, Magnusson P. Isozyme profile and tissue-origin of alkaline phosphatases in mouse serum. Bone 2013; 53:399-408.

III Halling Linder C, Enander K, Magnusson P.

Glycation contributes to interaction between human bone alkaline phosphatase and collagen type I.

Calcified Tissue International 2016; 98:284-293.

IV Halling Linder C, Ek-Rylander B, Krumpel M, Norgård M, Narisawa S, Millán JL, Andersson G, Magnusson P.

Bone alkaline phosphatase and tartrate-resistant acid phosphatase - potential coregulators of bone mineralization.

Manuscript 


\section{ABBREVIATIONS}

ALP

BALP

B/I, B1, B1x, B2

DEA

GCALP

GPI

GPI-PLC

GPI-PLD

HA

HPLC

IALP

$\mathrm{KO}$

LALP

L1, L2, L3

MV

OPN

PALP

PEA

PLP

pNPP

PPi

Pi

SPR

TNALP

TRAP

WT
Alkaline phosphatase

Bone alkaline phosphatase

Bone alkaline phosphatase isoforms

Diethanolamine

Germ cell ALP

Glycosylphosphatidylinositol

Glycosylphosphatidylinositol-specific phospholipase C

Glycosylphosphatidylinositol-specific phospholipase D

Hydroxyapatite

High-performance liquid chromatography

Intestinal alkaline phosphatase

Knockout

Liver alkaline phosphatase

Liver alkaline phosphatase isoforms

Matrix vesicle

Osteopontin

Placental alkaline phosphatase

Phosphoethanolamine

Pyridoxal 5'-phosphate

p-nitrophenylphosphate

Inorganic pyrophosphate

Inorganic phosphate

Surface plasmon resonance

Tissue-nonspecific alkaline phosphatase

Tartrate-resistant acid phosphatase

Wild-type 


\section{TABLE OF CONTENTS}

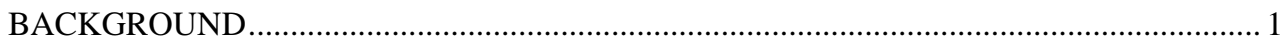

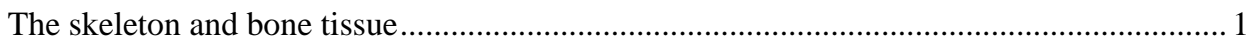

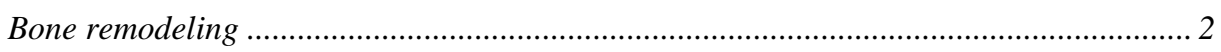

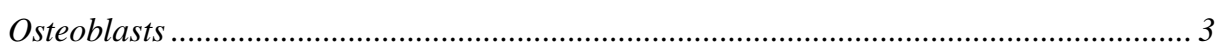

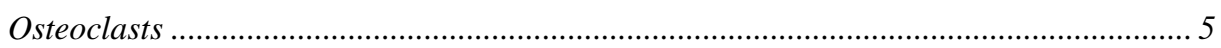

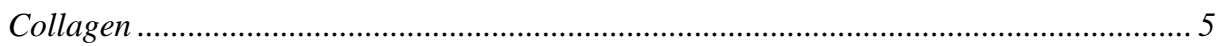

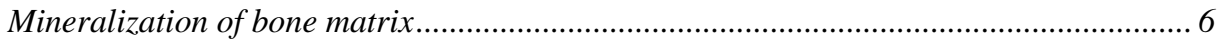

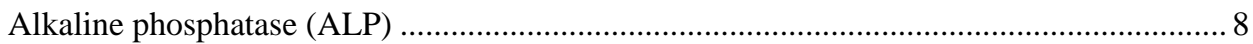

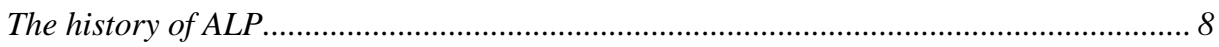

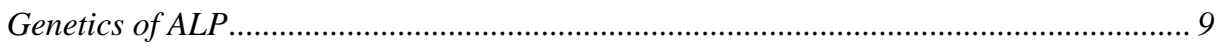

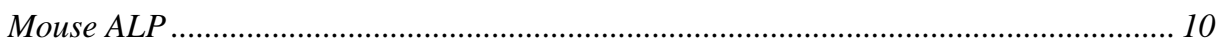

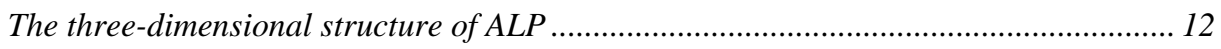

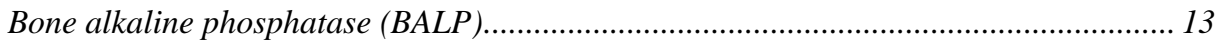

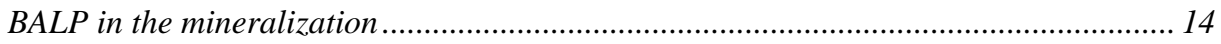

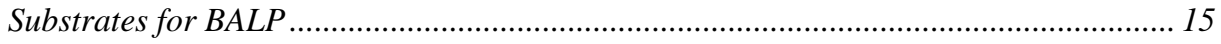

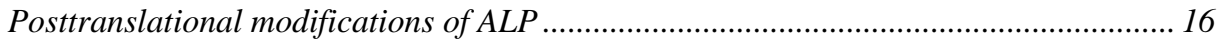

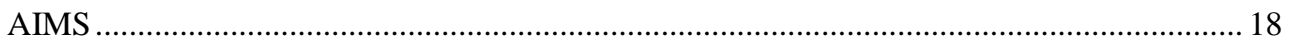

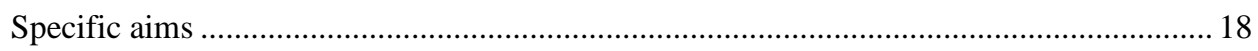

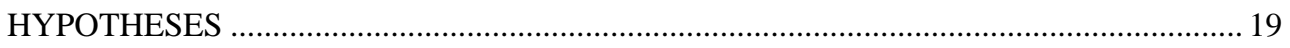

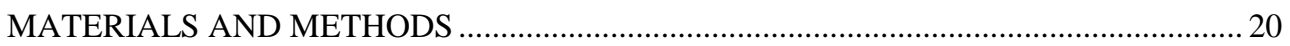

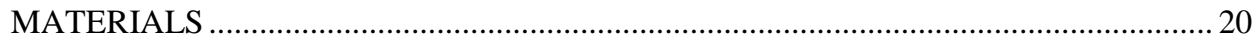

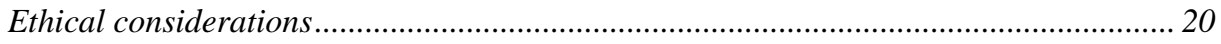

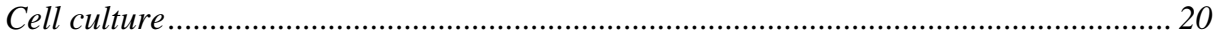

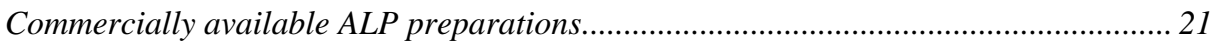

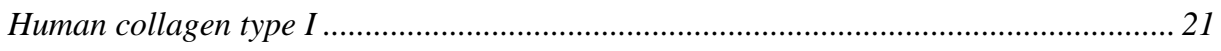

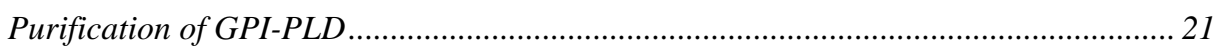

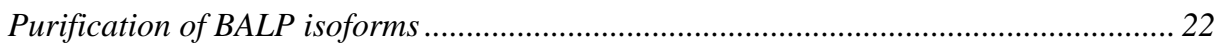

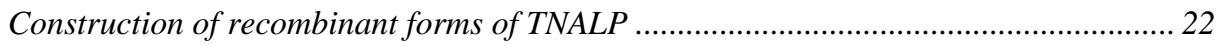

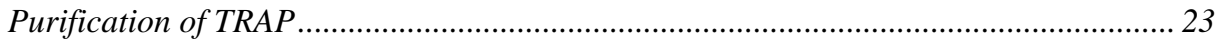

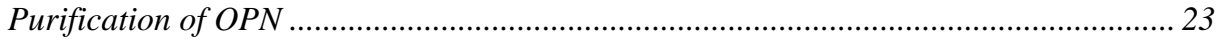

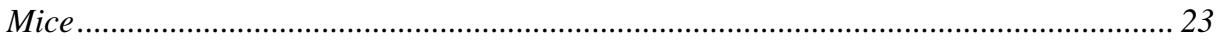

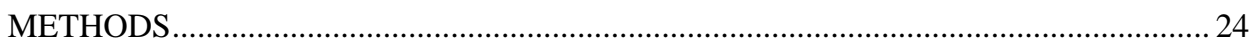

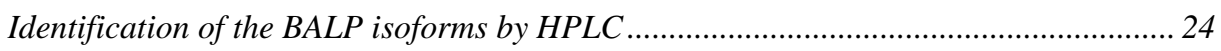

Measurements of ALP activity and protein concentration............................................... 25

Determination of glycosylation differences among the BALP isoforms ........................... 25 


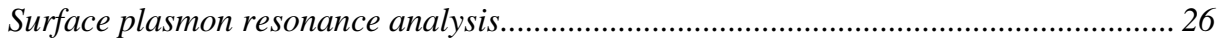

Electrophoresis, blotting and detection of ALP and collagen type I interactions ........... 28

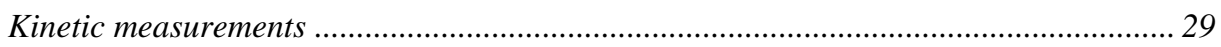

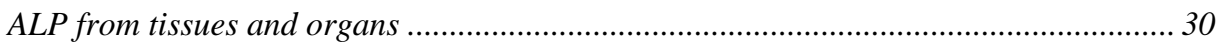

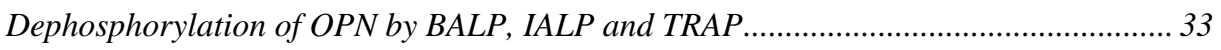

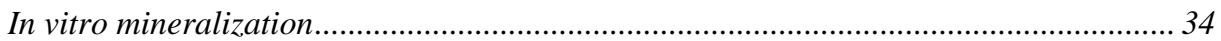

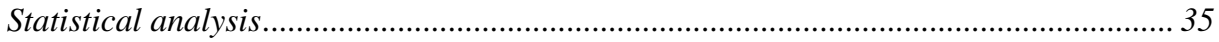

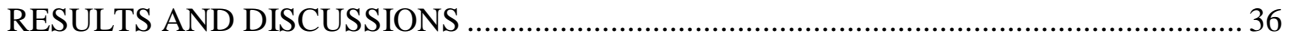

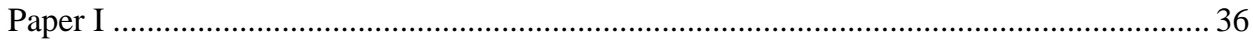

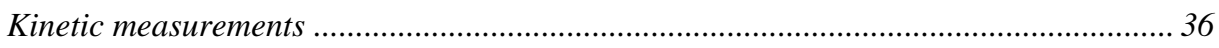

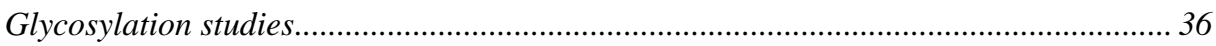

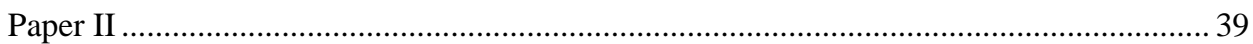

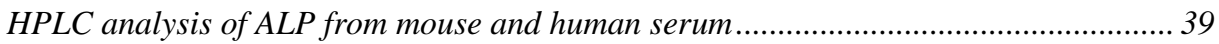

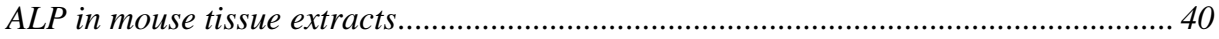

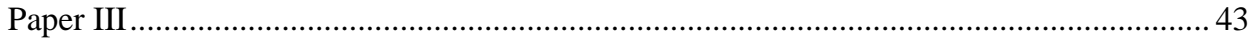

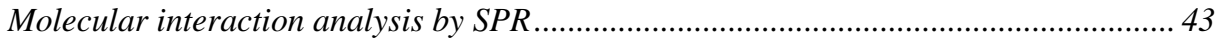

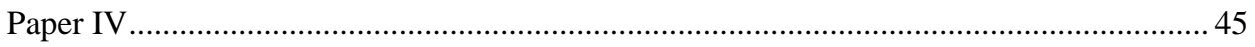

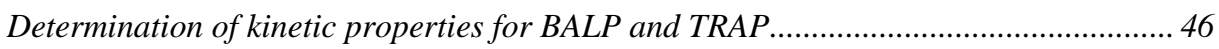

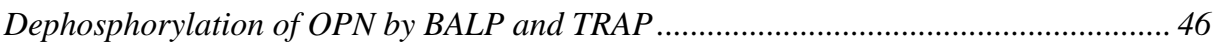

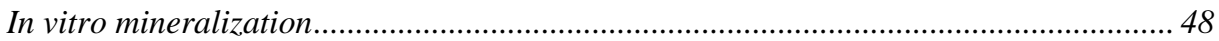

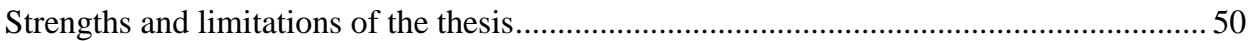

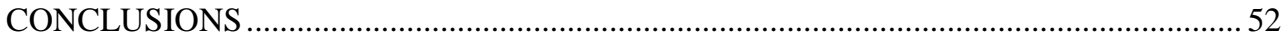

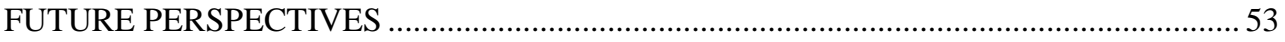

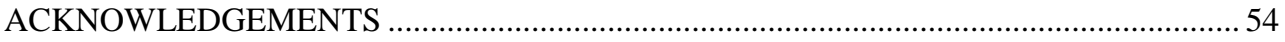

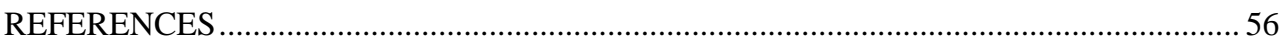




\section{BACKGROUND}

\section{The skeleton and bone tissue}

Bone, the material that makes vertebrates distinct from other animals, has evolved over several hundred million years of evolution to become a remarkable tissue. The human skeleton is a heterogeneous organ with wide morphologic, functional, and metabolic characteristics that has three major purposes. The first is mechanical, i.e., to keep the body upright and provide a framework for muscles to produce movement. The second is to protect vital organs and the hematopoietic tissues, and the third is to serve as a mineral reservoir, mainly for calcium. Bone is a material that has the same strength as cast iron, but achieves this while remaining as light as wood. The strength of bone is determined by its material composition and structure. It must be stiff in order to resist deformation and make loading possible, in addition to be flexible without cracking $[1,2]$. To achieve this, each bone has a specific shape, size and internal structure.

Bone is a composite material made up by two principle components: mineral crystals and collagen fibrils. The main part of bone is mineral, calcium and phosphate in the form of hydroxyapatite (HA), which provides the hardness of bone. Most bones have a mineral content of $60-70 \%$ depending on species, site and stage of development [3]. The rest, approximately $30 \%$, is made up of organic material, which gives the skeleton its elasticity and flexibility. Nearly $90 \%$ of the organic matrix consists of collagen type I, and the remaining $10 \%$ is proteins and enzymes [4]. The skeleton is also a reservoir for $99 \%$ of the body's calcium and approximately $1 \mathrm{~kg}$ is stored in bones and teeth [3].

Morphologically, there are two kinds of bone: trabecular bone, also named cancellous or spongy bone; and cortical bone, also named compact or dense bone. The adult human skeleton is composed of approximately $80 \%$ cortical bone and $20 \%$ trabecular bone [5]. The mechanical properties of any bone depend mainly on the mineral content (mineral-to-collagen ratio); the higher the mineral content the stiffer and more brittle (less tough) the bone. The best examples, provided by nature, are deer antlers with low mineralization but high impact 
resistance and, contrastingly, ear bones with high mineralization that need to be stiff for acoustical reasons $[6,7]$.

\section{Bone remodeling}

Bone is a living and dynamic tissue that, throughout the life span, constantly is being renewed in a process called bone remodeling. Old bone is resorbed and new bone is formed at the same location. Bone modeling is vigorous during growth, which is a process where bone is formed without prior resorption and bones change in size and shape. Both modeling and remodeling are necessary to give strength for loading and lightness for mobility. This is achieved by strategic deposition of bone in locations where it is needed to modify size and shape, and by removing bone from where it is not needed to avoid bulk. However, the ability to adapt bone structure to loading is limited after completion of longitudinal growth [8].

Normal bone remodeling is necessary for skeletal adaptation to mechanical use and during fracture healing, as well as for calcium homeostasis [9]. The properties of bones do not remain constant with age [10]. Age-related changes result in reduced height, which is caused by decreased bone mass that affect the axial (primarily trabecular) as well as the appendicular (primarily cortical) skeleton. Loss of bone mass, along with microarchitectural changes, leads to increased bone fragility and increased risk of fractures, also known as osteoporosis. Both men and women start losing bone mass between ages 30 and 40. However, women loose bone mass rapidly the first 5-10 years after menopause due to loss of estrogen [11], while men experience a slower and linear loss of bone [12]. In addition to losing bone faster, women accumulate less bone mass during growth in comparison with men. Consequently, the incident of bone fractures is 2- to 3-fold higher in women compared with men [13].

Remodeling sites may develop randomly, nontargeted, but can also be targeted to areas that are in need of repair $[14,15]$. Nontargeted remodeling is regulated by hormones like parathyroid hormone, thyroxine, growth hormone and estrogen. The main pathway is via modulation of osteoclasts which, via coupling between resorption and formation, subsequently affects osteoblast activity [16]. Targeted remodeling removes damaged bone through targeted resorption. In normal bone, osteocytes and their death by microdamage have been suggested to be the major event leading to the initiation of osteoclastic bone resorption [17].

In adult bone, the turnover rate is about 5-10\% each year with the entire skeleton replaced in 10 years [13]. This is achieved by combined actions of four different cell types: 
bone-forming osteoblasts [18]; bone-resorbing osteoclasts [19]; osteocytes that lie inside bone and functions as mechanosensors; [20] and bone lining cells that are thought to couple resorption and bone formation [21], or possibly by defining the bone remodeling compartments [22]. These bone cells balance the precise replacement of bone tissue over the years. However, due to aging, disease, or other factors, bone turnover may be imbalanced when resorption and replacement occurs in different rates. The remodeling sequence is about 200 days in trabecular bone [23] and 120 days in cortical bone [24]. In trabecular bone, the remodeling sequence has a resorption period of 30-40 days followed by bone formation over a period of approximately 150 days [25, 26] (Fig. 1). The remodeling rate is considered to be higher in trabecular bone in comparison with cortical bone [6].

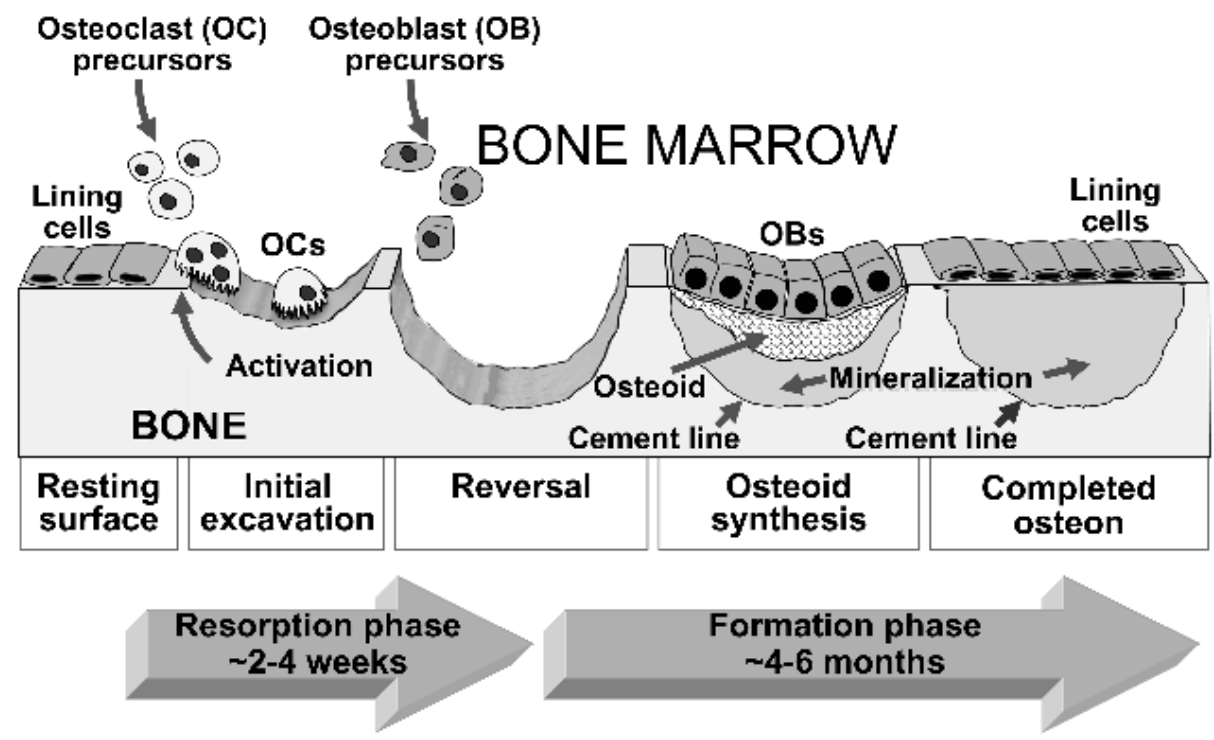

Figure 1. A simplified picture showing the various stages of cellular activity in bone remodeling. For simplicity of illustration, the remodeling is shown in only two dimensions, whereas in vivo it occurs in three dimensions, with osteoclasts continuing to enlarge the cavity at one end and osteoblasts beginning to fill it in at the other end. Printed with permission [27].

\section{Osteoblasts}

Osteoblasts, responsible for building both the organic and inorganic components of bone, are mesenchymal stem cells derived from mesodermal and neural crest progenitors [23]. The differentiation from mesenchymal stem cells towards the osteoprogenitor lineage requires 
specific genes and synthesis of several proteins. Expression of runt-related transcription factor 2 (RUNX2) is crucial for osteoblast differentiation and regulates the expression of several osteoblastic genes including the skeletal-specific osteocalcin gene, $\alpha 1(\mathrm{I})$ collagen, osteopontin $(\mathrm{OPN})$ and bone sialoprotein [23, 28]. Mice lacking RUNX2 are deprived of osteoblasts and have no skeletal development [29]. Once a pool of osteoprogenitors is established, they start to show alkaline phosphatase (ALP) activity and are considered to be preosteoblasts. The preosteoblasts undergo morphological changes, become larger and show higher ALP activity, active secretion of bone matrix proteins, and are considered as mature osteoblasts [30]. Fully differentiated osteoblasts are characterized by co-expression of collagen type I and ALP [31].

Mature osteoblasts appear as a single layer of cells covering all bone surfaces where one function is to synthesize the extracellular matrix. When an osteoblast stops forming bone, it has three ways to go: i) it can be embedded into the bone matrix and differentiate to an osteocyte [32], ii) it can stay on the bone surface and differentiate to a bone lining cell [33] or, iii) it can undergo programmed cell death (apoptosis) [13]. The majority of osteoblasts (50$70 \%$ ), initially found at remodeling sites, undergoes apoptosis [33].

The process where osteoblasts are embedded and differentiate to osteocytes is not fully understood. It has been speculated that it could be a passive process where osteoblasts slows down its matrix production and becomes "buried alive" under bone matrix produced by neighboring osteoblasts [34] or an active process with degradation of collagen [35]. Osteocytes lie in lacunae within the bone matrix and send their dendritic network through tunnels called canaliculi. This network connects to all cells on the bone surface. Osteocytes regulate both osteoblast and osteoclast functions, and regulates bone remodeling. They also act as mechanosensors and respond to mechanical loading of the skeleton and they may be a key target cell for the action of hormonal signaling regulating bone mass [20, 36].

The bone surface, not undergoing remodeling, is covered by a layer of unmineralized collagen matrix and, on top of this, a layer of flat and elongated osteoblasts named bone lining cells. Osteoclasts cannot attach to the unmineralized collagen. Therefore, other cells, possibly bone lining cells, secrete collagenase which removes collagen matrix so osteoclasts can attach to the bone surface. It has been proposed that osteocytes instruct lining cells to start secreting collagenase to initiate bone remodeling [13]. 


\section{Osteoclasts}

The main function of osteoclasts is to resorb mineralized bone, dentine and calcified cartilage and they are necessary for the initiation of normal bone remodeling. Osteoclasts can contain one but more often multiple nuclei and both mononuclear and multinuclear osteoclasts can resorb bone. The larger cells, the more effective in resorbing bone, although there is no direct relationship between the resorption capacity and the number of nuclei [37]. Osteoclasts are derived from hematopoietic stem cells and share a differentiation pathway with cells of the monocyte/macrophage lineages [38]. After proliferation in the bone marrow, mononuclear preosteoblasts are guided to the bone surface by mechanisms still unknown, and undergo fusion to form mature multinuclear osteoclasts [39]. The sequence of cellular events needed for bone resorption by the osteoclast is called resorption cycle, and an osteoclast can undergo several resorption cycles before undergoing apoptosis [40]. The attachment to the resorption site is mediated by integrins and the interaction with bone matrix is necessary for osteoclast activation. Immediately after attachment, activated osteoclasts undergo dramatic cytoskeleton plasma membrane reorganization resulting in specialized plasma membrane domains. First, the sealing zone is formed that seal the resorption site from the surroundings [41]. Second, the ruffled border is formed by fusion of intracellular acidic vesicles, with the plasma membrane facing the bone surface [42, 43], and develops long finger-like projections that penetrate the bone matrix. The extracellular space between the ruffled border membrane and the bone matrix is called resorption lacuna. The only endogenous process that is able to solubilize HA is low $\mathrm{pH}$, which is achieved by targeted secretion of hydrogen ions from the ruffled border into the resorption lacuna $[42,43]$. The sealing zone is tight enough to maintain a low $\mathrm{pH}$ in the resorption lacuna necessary for mineral dissolution [44]. After demineralization of bone matrix, the organic component is degraded by cathepsin $\mathrm{K}$, a lysosomal protease [45], tartrateresistant acid phosphatase (TRAP) and collagenase.

\section{Collagen}

The most abundant type of collagen in bone, collagen type I, is a fibril-forming collagen, which is synthesized as a procollagen precursor in the form of a helical rod consisting of two identical $\alpha 1$ helices and one different $\alpha 2$ helix. Every third amino acid residue in the triple helix is a glycine and the three parallel polypeptide strands coil around each other to form a right-handed triple helix. Posttranslational modifications, such as glycosylation, hydroxylation 
and cross-linking, of procollagen are essential for the synthesis of a stable extracellular matrix. The procollagen molecule contains non-triple helical extensions at each end, which are enzymatically removed as carboxy- and amino-terminal propeptides. Once these propeptides are removed, the triple helical collagen molecule can spontaneously self-assemble into collagen fibers. Collagen, with the propeptides still attached, can assemble but the lateral assembly of the triple helixes is limited and the fibrils become narrow [46]. The collagen fibers are further stabilized by cross-links within and between the triple helical units $[47,48]$. Valuable information about the importance of collagen organization in bone matrix can be obtained from diseases characterized by altered collagen matrix. Osteogenesis imperfecta, a genetic bone disorder, is characterized by fragile bones that break easily as a result of collagen abnormalities due to mutations primarily of the collagen type I genes [49]. Over 200 mutations leading to osteogenesis imperfecta has been identified but the most frequent is a point mutation that affects the conserved glycine residue leading to an triple helical disruption and an unstable collagen structure [50].

\section{Mineralization of bone matrix}

Mineralization of bone matrix is the final step of osteogenesis [51]. It is dependent on a series of physiochemical and biochemical processes that enables the deposition of mineral in the extracellular matrix. Mineralization is a two-step process that starts 5-10 days after the deposition of organic matrix by osteoblasts. When approximately $70 \%$ of the maximum mineral content is reached, the mineralization rate slows down and a secondary phase begins. This latter process consists of a slow and gradual maturation of the mineral content with an increase in crystal number and size [52].

The inorganic phase of bone matrix is mainly crystallized HA built up by calcium and phosphate $\left(\mathrm{Ca}_{10}\left(\mathrm{PO}_{4}\right)_{6}(\mathrm{OH})_{2}\right)$. In bones and teeth, the mineral is arranged as 50 to $150 \mathrm{~nm}$ stacks of 2.5 to $4 \mathrm{~nm}$ thick platelets [53]. The formation of HA crystals starts inside matrix vesicles (MV) that are released from osteoblasts by polarized budding of the plasma membrane [54]. HA crystals grow until they penetrate the MV membrane and become exposed to the extracellular environment [55-57] (Fig. 2). Isolated MVs contain a variety of enzymes, where ALP is the most notable $[58,59]$. ALP is concentrated to the outer surface of the MV membrane where it is attached to the membrane lipid bilayer with a glycosylphosphatidylinositol (GPI) anchor [60]. 


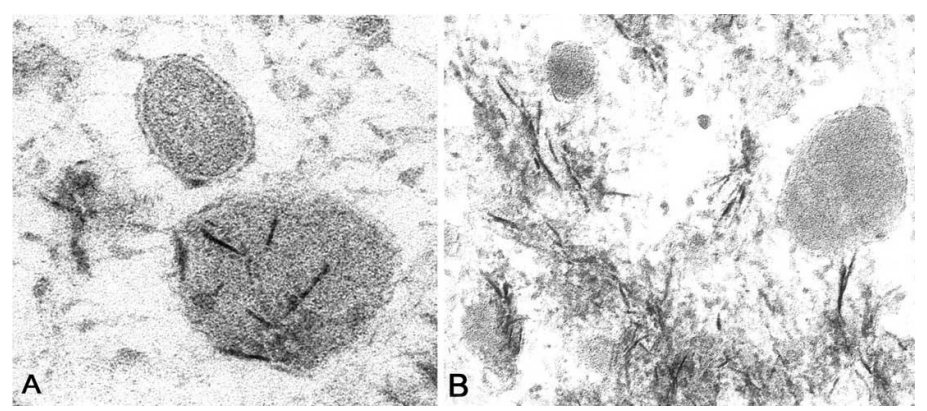

Figure 2. Mineralization in MVs. A. Early accumulation of needle-like HA crystals within the MVs in growth plate cartilage matrix. (x 250,000). B. Accumulation of extravesicular clusters of needle-like HA crystals (x 100,000). Printed with permission [61].

The deposition of HA inside of MVs is initiated by accumulation of phosphate by the activity of PHOSPHO1 on phosphoethanolamine (PEA) and phosphocholine. The influx of phosphate is generated extravesicular from inorganic pyrophosphate (PPi) and ATP by the enzymatic action of bone ALP (BALP) and the nucleotide pyrophosphatase/phosphodiesterase (NPP, EC 3.1.4.1) family that includes NPP1 (previously known as plasma cell membrane glycoprotein1, PC-1). PPi is present outside of MVs and acts as a potent inhibitor of crystal precipitation and growth by preventing free phosphate $(\mathrm{Pi})$ to crystallize with calcium [62]. OPN is another mineralization inhibitor that controls the degree of extracellular matrix mineralization by binding to HA as soon as it is exposed to the extracellular matrix. The co-expression of BALP and fibrillary collagen appears to be necessary for mineralization of the extracellular matrix [31]. The mechanism by which MV-initiated HA crystals transfer to collagen fibers remains elusive. However, some previous results suggest the formation of a collagen-ALP complex as a step in the process initiating the deposit of crystalline HA in and around collagen fibrils [63, 64] (Fig. 3). 


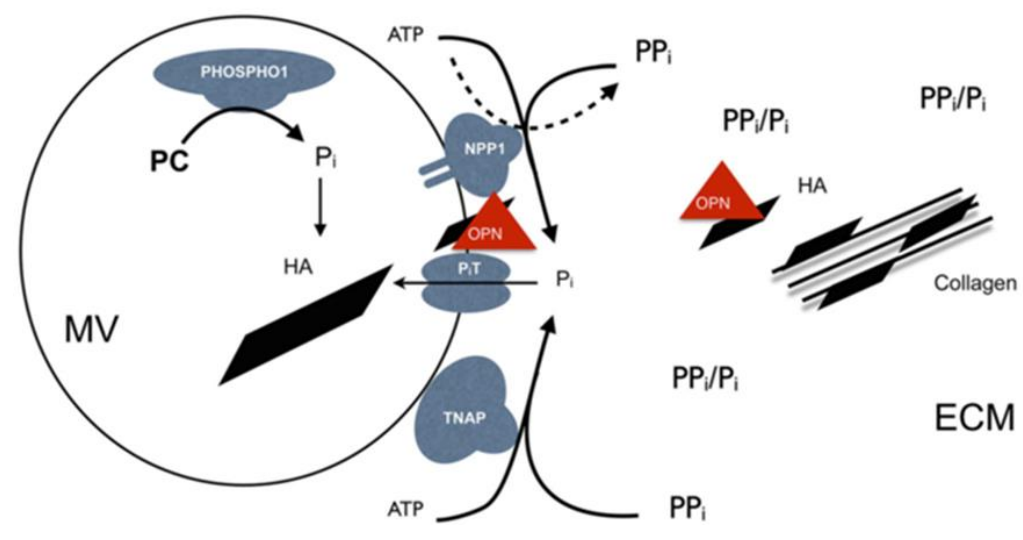

Figure 3. Summary model for the biochemical bases of MV-mediated initiation and propagation of bone mineralization. MVs initiate HA mineral deposition by accumulation of free phosphate $(\mathrm{Pi})$ generated intravesicularly by the action of PHOSPHO1 on phosphocholine (PC) and also via PiT-1-mediated incorporation of $\mathrm{Pi}$ generated extravesicularly by TNALP (TNAP in figure) or NPP1. The extravesicular propagation of mineral onto the collagenous matrix is mainly controlled by the pyrophosphatase activity of TNALP (TNAP) that establishes a PPi/Pi ratio conducive for controlled calcification. ECM = extracellular matrix. Printed with permission [65].

\section{Alkaline phosphatase (ALP)}

\section{The history of ALP}

During the late 19th century and early years of the 20th century, researchers found that phosphorous existed in organic and inorganic forms in living animals. The conversion of organic to inorganic phosphate in biological systems was investigated under the coming years by several researchers [66].

The first article on ALP (EC 3.1.3.1) was published in 1907 by Umetaro Suzuki et al. [67]. They stated that phosphatases are a separate group of enzymes and extracted ALP from rice and wheat, and referred to this enzyme as "phytase". Plimmer et al. [68] investigated how this "phytase" worked in animals and could draw the conclusion that organic phosphate was hydrolyzed to inorganic phosphate by a specific enzyme. It is in this article the word "phosphatase" was used for the first time [68]. The first report that addressed the importance 
of ALP for skeletal mineralization was in 1923 by Robert Robison [69]. Robison suggested that ALP increased the local concentration of phosphate by hydrolyzation of organic phosphate to inorganic phosphate. The liberated inorganic phosphate provides a substrate for mineralization that can be deposited together with calcium as HA. Robison found high activities of ALP in bone and cartilage of young rats and rabbits, and hypothesized that hydrolysis of hexosephosphoric esters was necessary for mineralization. The hypothesis from this article is still cited today and the article was republished in 1991 [70]. In 1924, Robison and Soames observed that the $\mathrm{pH}$ optimum was alkaline in vitro [71]. Soon after Robison's first report, this hypothesis was challenged when ALP was found in noncalcifying tissues such as liver, placenta and intestine [66]. Today, the importance of ALP in skeletal mineralization is proven and verified by the discovery and characterization of hypophosphatasia (HPP) [65, 72]. Measuring ALP activity in serum has been of significant clinical interest since the 1930s and high ALP activity indicates usually skeletal or hepatobiliary disease. Still, as of today, ALP is one of the most frequently used tests in routine clinical chemistry.

\section{Genetics of ALP}

ALP is a family of enzymes present in most species from bacteria to man [66]. For all ALPs, irrespectively of whether the origin is mammalian or bacterial, the function is to catalyze the hydrolysis of various phosphomonoesters at alkaline $\mathrm{pH}$ with the release of inorganic phosphates and alcohol $[73,74]$.

In humans, there are four genes that encode for the ALP isozymes (traditionally named after the tissue where they are predominantly expressed): intestinal ALP (IALP) encoded by the ALPI gene, placental ALP (PALP) encoded by the ALPP gene, and germ cell ALP (GCALP) encoded by the $A L P P 2$ gene. The fourth isozyme, encoded by the $A L P L$ gene, is expressed in bone, liver and kidney and is named tissue-nonspecific ALP (TNALP) [75, 76]. TNALP is expressed in high levels in bone and liver tissues, and accounts for approximately $95 \%$ of the total serum activity, with a ratio of approximately 1:1 in healthy adults [77] (Table $1)$.

The tissue-specific ALPs (i.e., IALP, PALP and GCALP) are clustered at the end of the long arm on chromosome 2, bands q34.2 - q37, with 90-98\% sequence identity, but only about 50\% identical to TNALP [78-80]. The TNALP gene is located to the short arm of chromosome 1 (1p36-p34) [79, 81]. While the TNALP gene is not highly polymorphic, the 
TNALP isozyme exists as numerous isoforms in biological fluids differing primarily in the extent and type of glycosylation [82-84] (Fig. 4).

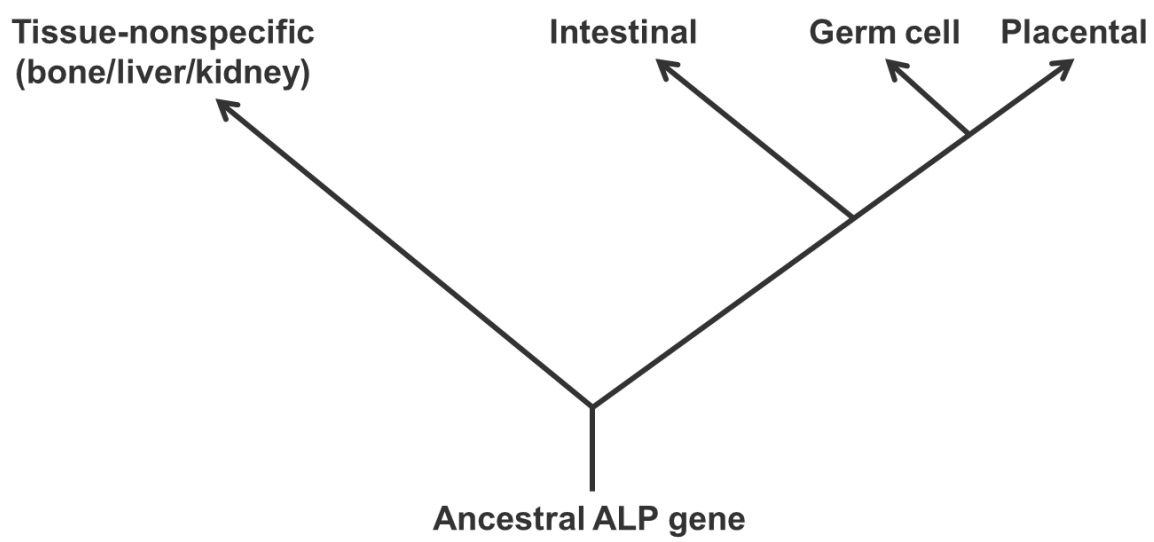

Figure 4. Evolutionary relationships of human ALP genes.

\section{Mouse ALP}

The mouse ALP genome is similar to the human organization but there are, however, some differences in the expression of the genetic isozymes. Fifty-two amino acids, out of 524 amino acids for the entire protein, are different between mouse and human TNALP on the protein level. There are five ALP loci described in the mouse genome: TNALP (Alpl, a.k.a. Akp2), embryonic ALP (EALP, Alppl2, a.k.a. Akp5), two different IALPs, i.e., the duodenumspecific IALP (dIALP) (Akp3 gene) and global IALP (gIALP) (Alpi, a.k.a. Akp6 gene), and a putative pseudo-ALP gene (Akp-ps1). In humans, the TNALP isozyme is mainly expressed in liver, kidney and bone, but TNALP is also expressed in the placenta during the first trimester of pregnancy and in the neural tube during development $[85,86]$. In mice, the TNALP gene Alpl is also expressed in placenta and primordial germ cells [87, 88]. EALP appears to be related to the human PALP and GCALP isozymes and is expressed under the early embryonic period, but is not detectable after embryonic day seven. The expression of IALPs in mice, dIALP and gIALP, is restricted to the intestine, but can also be expressed in thymus and embryonic stem cells. The ALP pseudogene (Akp-ps1) has high homology to EALP and IALP, but the gene is not transcribed [88-90] (Table 1). 
Table 1. Nomenclature of the human and mouse ALP isozymes and genes.

\begin{tabular}{llll}
\hline Gene & $\begin{array}{l}\text { Protein name } \\
\text { (abbreviation) }\end{array}$ & Tissue distribution & Function \\
\hline
\end{tabular}

\section{Human}

genes:

$A L P L$

$\begin{array}{lll}\begin{array}{l}\text { Tissue-nonspecific } \\ \text { alkaline phosphatase; }\end{array} & \begin{array}{l}\text { Developing nervous } \\ \text { system, skeletal }\end{array} & \begin{array}{l}\text { Skeletal } \\ \text { mineralization }\end{array} \\ \text { "liver-bone-kidney } & \text { tissue, liver and } & \\ \text { type" ALP (TNALP) } & \text { kidney } & \end{array}$
ALPP Placental alkaline phosphatase (PALP)
ALPP2 Germ cell alkaline phosphatase (GCALP)

Syncytiotrophoblast, a variety of tumors

Testis, malignant trophoblasts, testicular cancer

$\begin{array}{ll}\text { ALPI } & \begin{array}{l}\text { Intestinal alkaline } \\ \text { phosphatase (IALP) }\end{array}\end{array}$

Gut, influenced by

Fat absorption feeding and $\mathrm{ABO}$

Unknown blood group status

Unknown Detoxyfication of lipopolysaccharide

\begin{tabular}{|c|c|c|c|}
\hline $\begin{array}{l}\text { Mouse } \\
\text { genes: }\end{array}$ & & & \\
\hline $\begin{array}{l}\text { Alpl } \\
(A k p 2)\end{array}$ & $\begin{array}{l}\text { Tissue-nonspecific } \\
\text { alkaline phosphatase; } \\
\text { "liver-bone-kidney } \\
\text { type" ALP (TNALP) }\end{array}$ & $\begin{array}{l}\text { Developing nervous } \\
\text { system, skeletal } \\
\text { tissues and kidney }\end{array}$ & $\begin{array}{l}\text { Skeletal } \\
\text { mineralization }\end{array}$ \\
\hline Akp3 & $\begin{array}{l}\text { Duodenum-specific } \\
\text { intestinal alkaline } \\
\text { phosphatase (dIALP) }\end{array}$ & Gut & $\begin{array}{l}\text { Fat absorption } \\
\text { Detoxyfication of } \\
\text { lipopolysaccharide }\end{array}$ \\
\hline $\begin{array}{l}\text { Alppl2 } \\
(\text { Akp5) }\end{array}$ & $\begin{array}{l}\text { Embryonic alkaline } \\
\text { phosphatase (EALP) }\end{array}$ & $\begin{array}{l}\text { Preimplantation } \\
\text { embryo, testis, gut }\end{array}$ & $\begin{array}{l}\text { Early } \\
\text { embryogenesis }\end{array}$ \\
\hline$A k p-p s 1$ & $\begin{array}{l}\text { ALP pseudogene, } \\
\text { pseudoALP }\end{array}$ & Not transcribed & \\
\hline $\begin{array}{l}\text { Alpi } \\
(\text { Akp6) }\end{array}$ & $\begin{array}{l}\text { Global intestinal } \\
\text { alkaline phosphatase } \\
\text { (gIALP) }\end{array}$ & Gut & Under investigation \\
\hline
\end{tabular}




\section{The three-dimensional structure of ALP}

For many years, the only structural information of ALP was based on information from bacterial E. coli ALP [91-94]. The structural and catalytic mechanisms found in E. coli ALP were proposed to be similar in eukaryotic ALPs. The first mammalian ALP structure was resolved by Le Du et al. [95] in 2001 who resolved the three-dimensional structure of human PALP. PALP is a dimer and each monomer contains 484 residues, four metal atoms, one phosphate ion and 603 water molecules. Mammalian ALPs have low sequence identity with E. coli ALP (25-30\%) but the active site residues and the residues coordinating the metal ions necessary for enzyme activity are largely conserved $[76,91,96]$. The surface of PALP has been poorly preserved in comparison with $E$. coli ALP, with only $8 \%$ residues in common. The human TNALP gene was sequenced by Weiss et al. in 1988 [75]. The three-dimensional structures of human IALP, GCALP and TNALP have been predicted based on their sequence homology to PALP revealing that the novel features discovered in PALP are conserved in all human ALP isozymes [97].

Two monomeric ALPs, related by a two-fold axis with strong hydrophobic character, must form a homodimer to function physiologically [97, 98]. The dimer interface is of critical importance for stability and enzymatic function, and all ALPs are, therefore, obligatory homodimers. Mammalian ALPs are allosteric enzymes, where the binding of the substrate in one active site affects the second active site. The stability and the catalytic properties of each monomer are controlled by the conformation of the second subunit [99]. An amino-terminal $\alpha$-helix from each monomer reaches out and embraces the other subunit, stretching toward its active site and conferring allosteric properties to the dimer [100]. A flexible domain on the top of the ALP molecule, the crown domain, has been associated with collagen binding [101, 102]. Both the crown domain and the amino-terminal $\alpha$-helix stabilizes the dimeric structure and determine allosteric properties [99]. Three metal-binding sites, surrounding the active site, are essential for enzymatic activity. Two of these sites are occupied by one magnesium ion and two zinc ions [95, 103]. The determined PALP structure [95] revealed also an additional noncatalytic metal-binding site that appears to be occupied by calcium [104]. A number of patients with severe forms of HPP have mutations affecting this site, which is an indication of the significance of this calcium binding site [104]. The crown domain, the amino-terminal arm, and the calcium binding site are all found in mammalian ALPs but are absent in bacterial ALP (Fig. 5). 


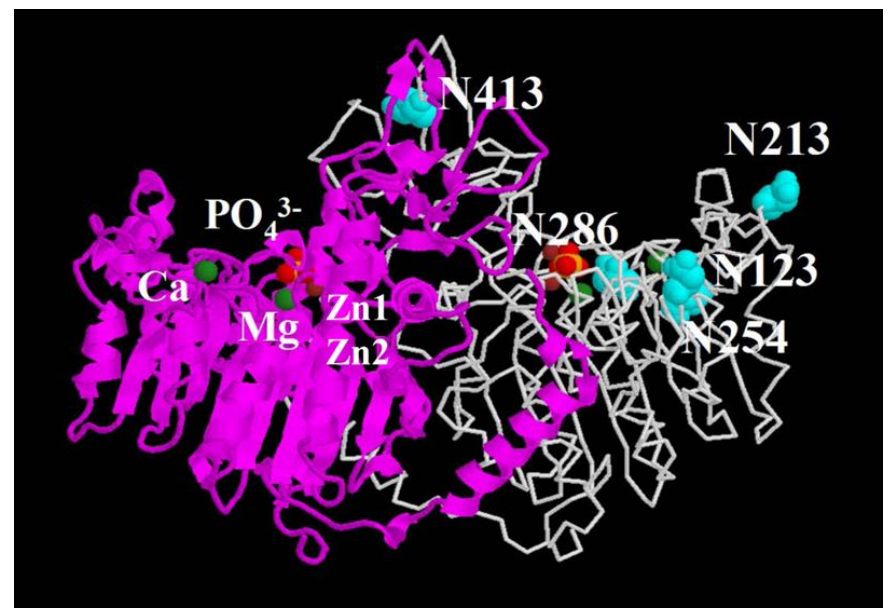

Figure 5. Overall structure of the TNALP molecule illustrated as a homodimer. Subunit A is shown in white with backbone representation and subunit $B$ is shown in magenta with ribbon representation. The five putative $\mathrm{N}$-glycosylation sites (i.e., Asn residues) with terminal sialic acid residues are highlighted in subunit $\mathrm{A}$ with space-filling models in cyan. The active site phosphate $\left(\mathrm{PO}_{4}{ }^{3-}\right), \mathrm{Zn}$ and $\mathrm{Mg}$ ions are pointed out in subunit $\mathrm{B}$ as well as the fourth metal site likely to be occupied by calcium. Printed and modified with permission [105].

\section{Bone alkaline phosphatase (BALP)}

BALP functions as an ectoenzyme attached to the cell membrane lipid bilayer by a GPI anchor [106, 107]. A variety of enzymes are found on the surface of MVs but BALP is particularly enriched [58, 59]. BALP is released into the circulation by the action of circulating GPI-phospholipase C (GPI-PLC) and GPI-phospholipase D (GPI-PLD) [108-110].

At least six different TNALP isoforms can be separated and quantified by weak anionexchange high-performance liquid chromatography (HPLC), in serum from healthy individuals, three BALP isoforms (B/I, B1 and B2) and three liver ALP (LALP) isoforms (L1, L2 and L3) [77]. The B/I peak contains mainly BALP but also the small fraction of IALP, which is present in the circulation (however, this is only approximately $30 \%$ of the peak area for $\mathrm{B} / \mathrm{I}$ ) while the $\mathrm{B} 1$ and $\mathrm{B} 2$ isoforms are pure bone isoforms. A fourth bone-specific ALP isoform, identified as B1x, has also been demonstrated in serum from patients with chronic kidney disease [111, 112], and in extracts of human bone tissue [113] (Fig. 6). The circulating levels of these isoforms can vary independently during the pubertal growth spurt and in metabolic bone disease [114], and they differ also with respect to their distribution in cortical and trabecular bone [113]. 

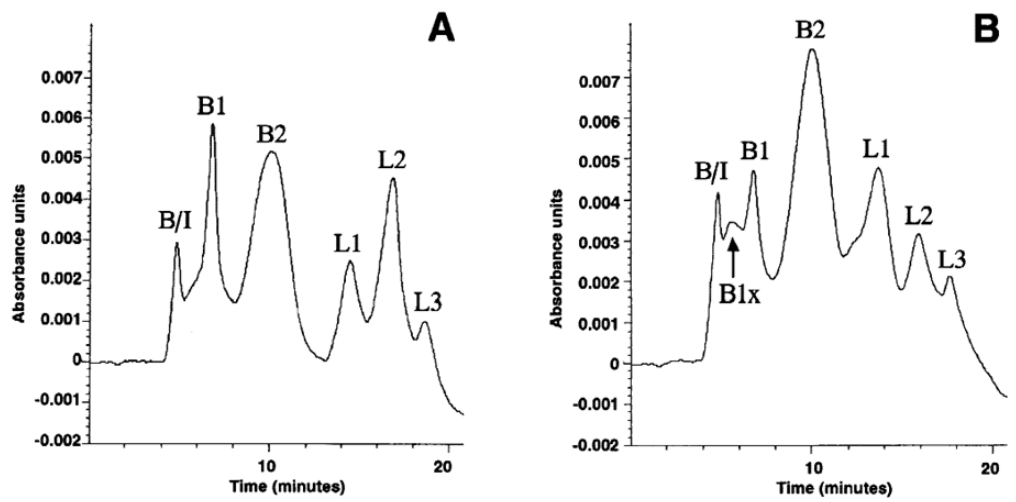

Figure 6. (A) A serum ALP isoform profile from a healthy female. (B) A serum ALP isoform profile from a female patient with severe renal insufficiency and on chronic dialysis therapy. Printed with permission [115].

\section{BALP in the mineralization}

The importance of BALP for the mineralization process is illustrated by HPP (OMIM\#: $146300,241500,241510$ ), a rare inborn-error-of-metabolism that features rickets or osteomalacia [72] [116]. All HPP patients carry one or more loss-of-function mutations in their ALPL gene leading to deficient TNALP activities (and thereby extracellular accumulation of PPi), low or subnormal serum ALP activities, and defective bone and tooth mineralization [117]. The clinical expression of HPP is highly variable and is classified into six different forms: perinatal lethal, perinatal benign, infantile, childhood, adult, and odontohypophosphatasia. The prognosis for each of these HPP forms depend upon the severity of the skeletal disease which reflects the age at presentation, i.e., the earlier a patient manifests skeletal symptoms, the more severe HPP. The more severe forms (perinatal and infantile) are inherited as an autosomal recessive trait while both autosomal recessive and autosomal dominant transmission can be found in the milder forms [118, 119].

Much of our knowledge about the function of BALP is based on observations from mouse models of HPP. In the 1990s, two different mouse models of HPP were developed independently of each other. These Alpl global knock out (KO) mouse models were the $\mathrm{Alpl}^{\mathrm{tm} 1 \mathrm{Sor}}$ mouse model [90] and the $\mathrm{Alpl}^{\mathrm{tm} 1 \mathrm{Jlm}}$ mouse model [88]. Characterization and comparison of these two mouse models showed that bone abnormalities appeared at approximately 10 days of age, and osteopenia and fractures worsened thereafter. Both KO 
mouse models had elevated urinary levels of PEA and PPi and elevated plasma pyridoxal 5'phosphate (PLP) levels [120].

\section{Substrates for BALP}

BALP has broad substrate specificity in vitro, but only a few compounds have been proposed to be natural substrates for BALP in vivo. By studying patients with HPP, three endogenous substrates for BALP have been suggested: PPi, PLP and PEA, since these three phosphocompounds accumulate in patients with HPP (Fig. 7). Studies of TNALP KO mice have provided proof that the major function for TNALP in bone tissue is to hydrolyze the mineralization inhibitor PPi in order to maintain a proper PPi/Pi ratio. The reduction of PPi by BALP is crucial for extravesicular growth of HA crystals, and for generating Pi for HA crystallization. Mice deficient in TNALP show high extracellular PPi levels and impaired skeletal mineralization $[121,122]$. Patients with HPP have also high circulating levels of PLP, the major circulating form of vitamin B6. This vitamin is a cofactor for over a hundred different enzymes. For example, PLP is the cofactor for the catabolism of many different amino acids, and necessary for the synthesis of several different neurotransmitters. BALP removes one phosphate from PLP forming pyridoxal (PL) [123, 124]. It is only the nonphosphorylated form of PLP (i.e., PL) that is able to pass through cell membranes and into cells or the central nervous system. Once inside the cell, PL is phosphorylated to form PLP again and can act as a cofactor for enzymatic pathways. TNALP deficiency results in high extracellular levels of PLP and low circulating levels of PL. This gives an insufficient incorporation of PL into the central nervous system and low intracellular levels of PLP resulting in vitamin B6-dependent seizures [125]. In TNALP KO mice, the absence of TNALP results in severe neurological symptoms such as hypomyelination and thinning of the spinal nerves, and mortality after weaning always caused by seizure [88, 126]. The urinary levels of PEA are increased in HPP patients and in TNALP deficient mice; however, the metabolic pathway for accumulation of PEA is unknown [127]. 
<smiles>O=P(O)(O)OP(=O)(O)O</smiles><smiles>Cc1ncc(COP(=O)(O)O)c(C=O)c1O</smiles><smiles>NCCOP(=O)(O)O</smiles>

Inorganic pyrophosphate (PPi)

Pyridoxal 5'-phosphate (PLP; Vitamin B6)

Figure 7. Proposed endogenous substrates for BALP.

\section{Posttranslational modifications of ALP}

Glycosylation is the most common form of posttranslational modification of proteins and most mammalian plasma membrane and secretory proteins are glycosylated. These modifications can greatly affect physical properties and biological functions of the protein [128]. There are two major types of glycans, N-linked and O-linked. N-linked glycans are linked to asparagine residues in an Asn-X-Ser/Thr motif [129], and O-linked glycans are linked to serine or threonine [130]. All N-linked glycans have a core structure of five sugars that differ in their outer branches. In the O-linked glycans, the oligosaccharides range in size from 1 to more than 20 sugars and display, therefore, considerable structural diversity [131]. Glycosylation produces numerous structural modifications and increasing evidence indicates that these carbohydrates are important for protein sorting, cell signaling, immune and receptor recognition and cell differentiation among other processes [132] (Fig. 8).

Predicted from amino acid sequences, TNALP have five possible N-glycosylation sites while the tissue-specific ALPs (i.e., IALP, GCALP and PALP) have two sites [76, 133]. It has later been confirmed that all TNALPs are N-glycosylated and that bone and kidney ALP are O-glycosylated but not LALP [82, 134]. The two sites in GCALP are occupied by N-glycans and deletion of either one, or two of these glycans, do not affect the enzymatic activity of GCALP [135]. 


\section{O-linked oligosaccharides}

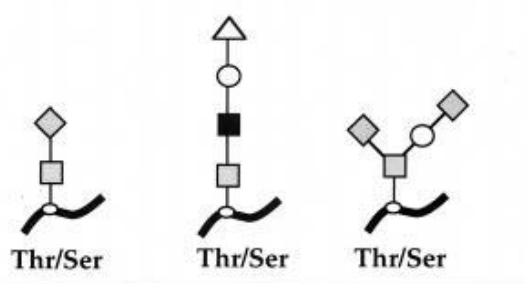

\section{N-linked oligosaccharides}

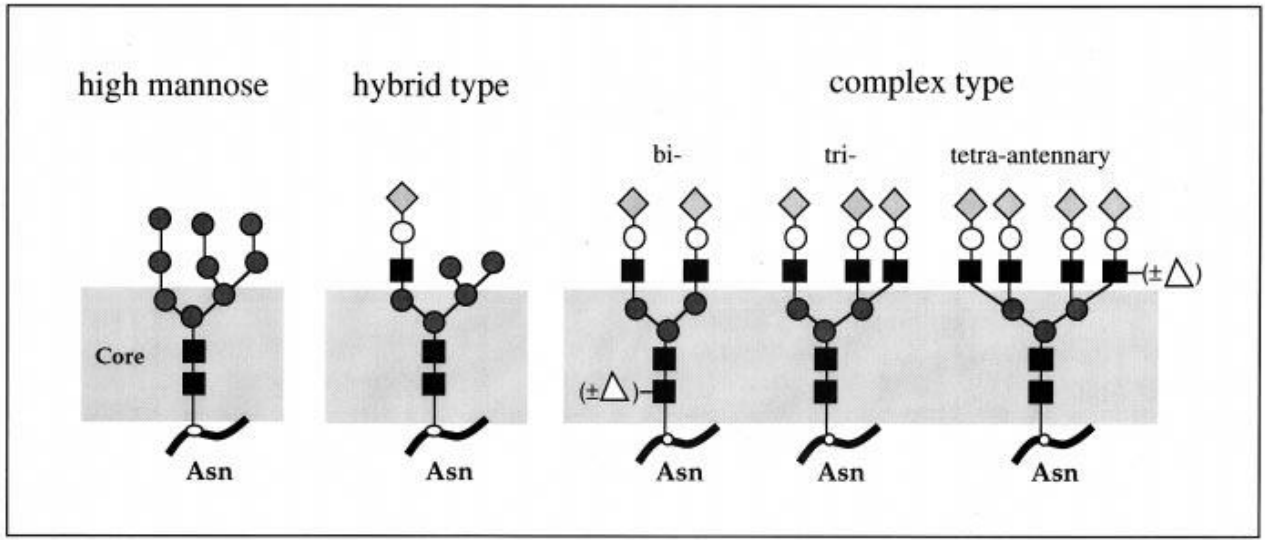

Figure 8. O- and N-linked oligosaccharide structures. (Top), examples of O-linked oligosaccharides. (Bottom), different structures of N-linked oligosaccharides.

$\square$, N-Acetylgalactosamine; $\square$, N-acetylglucosamine; $\bigcirc$, galactose; $\bigcirc$, mannose; $\triangle$, fucose; $\diamond$, sialic acid; $\sim$, polypeptide chain. Printed with permission [131]. 


\section{AIMS}

The overall aim of this thesis was to gain further insight regarding the role of mammalian BALP isoforms in bone and mineral metabolism with respect to their biochemical and functional properties.

\section{Specific aims}

To investigate the catalytic properties of the BALP isoforms and recombinant forms of TNALP towards the postulated endogenous substrates (i.e., PPi, PLP and PEA).

To investigate the role of posttranslational glycosylation patterns among the BALP isoforms influencing their catalytic properties.

To characterize circulating and tissue-derived mouse ALP isozymes and isoforms from wild-type (WT) and different ALP knockout mice strains and to study the function, distribution and similarities in relation to the human ALP isozymes and isoforms.

To investigate the binding properties of human collagen type I to human BALP, including the two BALP isoforms B1 and B2, and the importance of posttranslational glycosylation for these interactions.

To investigate BALP and TRAP regarding their substrate specificity towards the known endogenous substrates for BALP (i.e., PPi and PLP), and their impact on mineralization in vitro by dephosphorylation of OPN. 


\section{HYPOTHESES}

The structural differences among the BALP isoforms are due to different posttranslational glycosylation patterns that influence the catalytic properties of these isoforms towards endogenous substrates.

Mice have the same BALP isoforms as humans and could therefore be used as an animal model to further study the biological role of the BALP isoforms during osteogenesis.

BALP binds with higher affinity to collagen type $I$ in comparison with ALPs expressed in non-mineralizing tissues, primarily due to posttranslational glycosylation modifications.

TRAP has enzymatic activity towards the endogenous substrates for BALP (PPi and PLP).

Both BALP and TRAP can dephosphorylate OPN, which decreases the inhibitory capacity of OPN during mineralization in vitro. 


\section{MATERIALS AND METHODS}

A vast array of methods was used throughout the work of this thesis. The most important experimental techniques used are explained in this chapter. Other methods and detailed information about the used experimental procedures are described in papers I-IV.

\section{MATERIALS}

\section{Ethical considerations}

All mice, WT and various KO models, used in these studies were housed at Sanford Burnham Prebys Medical Discovery Institute's vivarium following the guide standards (e.g., contact bedding, temperature and humidity control) and approved under Animal Usage Form \#13094. Animal technicians conducted routine husbandry procedures and daily health checks to assess the animals' condition. To collect blood and tissue samples, mice were anesthetized with Avertin ( $0.017 \mathrm{~mL} / \mathrm{g}$ body weight) and after confirmation of deep sleep exsanguinated by cardiac puncture. Institution's Animal Care \& Use Program is accredited by AAALAC International (Association for Assessment and Accreditation of Laboratory Animal Care) and a Multiple Project Assurance A3053-1 is on file in the OLAW, DHHS (Office of Laboratory Animal Welfare, Department of Health and Human Services).

\section{Cell culture}

The BALP isoforms used in papers I, II and III were purified from a stable subpopulation of human osteoblast-like SaOS-2 cells (ATCC, American Type Culture Collection, Manassas, VA, USA) that were selected for high production of BALP [136, 137]. SaOS-2 cells were used since their BALP activity have been reported to be structurally, immunologically and kinetically indistinguishable from normal human BALP [83, 113, 136-139]. The SaOS-2 cells were grown in Dulbecco's modified Eagle's medium (high glucose), supplemented with 10\% 
fetal calf serum, $1 \%$ penicillin/streptomycin, $40 \mathrm{U} / \mathrm{mL}$ nystatin and incubated at $37^{\circ} \mathrm{C}$ with 95\% humidity and $5 \% \mathrm{CO}_{2}$. Medium was removed when cells reached confluency, and cells were washed with phosphate-buffered saline (PBS) and stored at $-20^{\circ} \mathrm{C}$ for later extraction of BALP.

\section{Commercially available ALP preparations}

In papers III and IV, different types of commercially available ALPs were used. Human BALP, LALP and PALP were all obtained from Calzyme Laboratories Inc. (San Luis Obispo, CA, USA) and E. coli ALP from Sigma-Aldrich (St. Louis, MO, USA).

\section{Human collagen type I}

The collagen used in paper III for interaction analysis was a commercially available nativelike human collagen type I preparation purified from human neonatal fibroblasts, with a purity of $\geq 99.9 \%$ (determined by SDS-PAGE) (Advanced BioMatrix Inc., San Diego, CA, USA). This collagen preparation comprises $97 \%$ collagen type I and the remainder is collagen type III. The amino- and carboxy-terminal ends are removed by pepsin treatment in order to reduce the potential of in vivo immunogenicity responses. There are no cross-links present in this collagen preparation and the collagen does not self-assemble into collagen fibrils.

\section{Purification of GPI-PLD}

BALP functions as an ectoenzyme and is attached to the osteoblast cell membrane with a GPI anchor $[140,141]$. In all studies, BALP was cleaved off from the GPI-anchor by GPI-PLD to become GPI-anchor-free (soluble).

GPI-PLD was purified from commercially available human serum (Sigma-Aldrich). To remove insoluble materials, serum was incubated with $9 \%$ polyethylene glycol for 1 hour, centrifuged, and the pellet was removed. The supernatant was filtered through a $0.22 \mu \mathrm{m}$ filter, centrifuged through a Vivaspin 20 concentrator, MWCO $300 \mathrm{kDa}$ (Vivascience AG, Hannover, Germany), concentrated with aquacide and dialyzed in Tris buffer, $\mathrm{pH}$ 7.8, containing $\mathrm{NaCl}$ and $\mathrm{CaCl}_{2}$ (Buffer A) before applied to a DEAE Sepharose column. After elution with $0.010-0.500 \mathrm{M} \mathrm{NaCl}$ (total volume $500 \mathrm{~mL}$ ) in Buffer A, each fraction was 
tested for GPI-PLD activity as reported elsewhere [113]. Fractions that contained GPI-PLD were pooled, concentrated, and dialyzed in Buffer A. The solution containing GPI-PLD was applied to a Concanavalin A column and eluted with $0.1 \mathrm{M}$ glucose in Buffer A. The fractions containing GPI-PLD was pooled, concentrated, dialyzed with Buffer A and stored at $-70^{\circ} \mathrm{C}$.

\section{Purification of BALP isoforms}

In brief, SaOS-2 cells were homogenized in a Tris buffer, $\mathrm{pH} \mathrm{8.3,} \mathrm{with} \mathrm{benzamidine} \mathrm{and}$ phenylmethylsulfonyl, and incubated in ice-cool butanol to a final concentration of $30 \%$ for 24 hours at $4^{\circ} \mathrm{C}$. Homogenized cells were centrifuged to separate in two phases, and the lower phase was collected and dialyzed in Tris buffer, $\mathrm{pH} 8.3$, with $\mathrm{MgCl}_{2}$ and zinc acetate to remove butanol. GPI-PLD was added, to solubilize the BALP preparation, to a final concentration of $25 \%$ and incubated for 16 hours at $37^{\circ} \mathrm{C}$. To separate soluble (anchordepleted) BALP from insoluble (anchor-intact) BALP, the preparation was incubated 1:1 in Tris buffer, $\mathrm{pH} 8.3$, containing $\mathrm{MgCl}_{2}$, zinc acetate and $4 \%$ Triton $\mathrm{X}-114$, for $30 \mathrm{~min}$ at $37^{\circ} \mathrm{C}$ and centrifuged to separate the two phases. The upper phase containing soluble BALP was collected, concentrated and dialyzed in Tris buffer, $\mathrm{pH} 8.5$, with $\mathrm{NaHCO}_{3}$ and zinc acetate before applied to a Q-Sepharose column, and eluted with 0.05-0.20 M sodium acetate in Tris buffer, $\mathrm{pH}$ 7.6, containing zinc acetate. The BALP isoforms were identified by HPLC.

\section{Construction of recombinant forms of TNALP}

The TNALP-flag isoform used in paper I was constructed with the TNALP cDNA (ATCC no. 59635) as a template. To facilitate isolation, a FLAG epitope (5'-TTA CTT GTC ATC GTC GTC CTT GTA GTC-3’) and a termination codon to eliminate the GPI-anchoring signal was introduced [142]. The other recombinant form used in paper I, SALP-FcD 10 , contains recombinant human TNALP (sALP), the constant region of human IgG1 Fc domain (Fc), and a deca-aspartate $\left(\mathrm{D}_{10}\right)$ motif for targeting to mineralizing tissue $[143,144]$. Today, sALP$\mathrm{FcD}_{10}$ is named asfotase alfa $\left(\right.$ Strensiq $^{\circledR}$ ) marketed by Alexion Pharmaceuticals, Inc. (formerly Enobia Pharma) and was recently approved for enzyme-replacement therapy for patients with perinatal/infantile- and juvenile-onset HPP [145]. 


\section{Purification of TRAP}

In paper IV, we used recombinant human TRAP 5a purified from concentrated Baculovirusinfected Spodoptera frugiperda (Sf9) insect cell culture supernatant (GenScript USA Inc., Piscataway, NJ, USA) performed according to a previously published protocol [146]. For proteolytic cleavage of TRAP 5a to enzymatically active TRAP 5b, human liver cathepsin L (Merck Millipore, Darmstadt, Germany) was used according to Krumpel et al. [146].

\section{Purification of OPN}

Bovine milk OPN, used in paper IV, was purified according to Bayless et al. [147] as modified by Ljusberg et al. [148]. In brief, OPN was purified from 1 liter of raw bovine milk, after addition of a protease inhibitor cocktail (Roche Diagnostics Scandinavia AB, Bromma, Sweden), using one DEAE Sepharose Fast Flow column (GE Healthcare Bio-Sciences AB, Uppsala, Sweden) and two consecutive Phenyl Sepharose Fast Flow columns (GE Healthcare Bio-Sciences AB). The identity and purity of the isolated OPN were confirmed by aminoterminal sequence analysis, and the concentration was determined by total amino acid analysis.

\section{Mice}

The presence of ALP in mouse liver was investigated by histochemical staining, Northern and Western blot analysis of liver tissues in paper II. Mouse tissues and serum were collected from four different WT mice strains, 8-week-old males (5 in each group): C57B1/6J and BALB/c male mice (Jackson Laboratory, Sacramento, CA, USA) and FVB/N and ICR male mice (Taconic Farm Inc., Oxnard, CA, USA). The ApoE-TNALP transgenic (Tg) (+) mouse line expressing human TNALP was used as positive control for ALP histochemical staining and Western blot analysis [31].

In paper IV, a TNALP KO mouse and a TNALP transgenic mouse was used to study the quantity and distribution of TRAP, TNALP and OPN in the different mouse lines. The used TNALP KO line was originally produced in hybrid backgrounds of 129 and C57B1/6 mice, and the Col1a1 TNALP transgenic mice was first generated in a FVB/N strain. The two lines had been crossed for more than 15 generations. Mice with the genotypes, WT, TNALP KO (Alpl 
${ }^{\prime-}$; a.k.a. $\left.A k p 2^{-/}\right)$and TNALP transgenic mice (ColTg; $\left.A l p l^{+/+}\right)$, were obtained from this crossed line [88, 149].

\section{METHODS}

\section{Identification of the BALP isoforms by HPLC}

In papers I, II and III, isoforms and isozymes of ALP were determined by a previously described HPLC assay [150, 151]. In brief, the various ALP forms were separated using a gradient of 0.6 M sodium acetate on a weak anion-exchange column, SynChropak AX300 $(250 \times 4.6 \mathrm{~mm}$ I.D.) (Eprogen, Inc., Darien, IL, USA). In order to detect ALP activity the column effluent was mixed on-line with the substrate solution $(1.8 \mathrm{mM}$ pnitrophenylphosphate (pNPP) in a $0.25 \mathrm{M}$ diethanolamine (DEA) buffer at $\mathrm{pH} 10.1$ ) and the ensuing reaction took place in a packed bed postcolumn reactor at $37^{\circ} \mathrm{C}$. The formed product (p-nitrophenol) was then directed on-line through the detector set at $405 \mathrm{~nm}$ (Fig. 9). The areas under each peak were integrated and the total ALP activity was used to calculate the relative activity of each of the detected ALP forms.

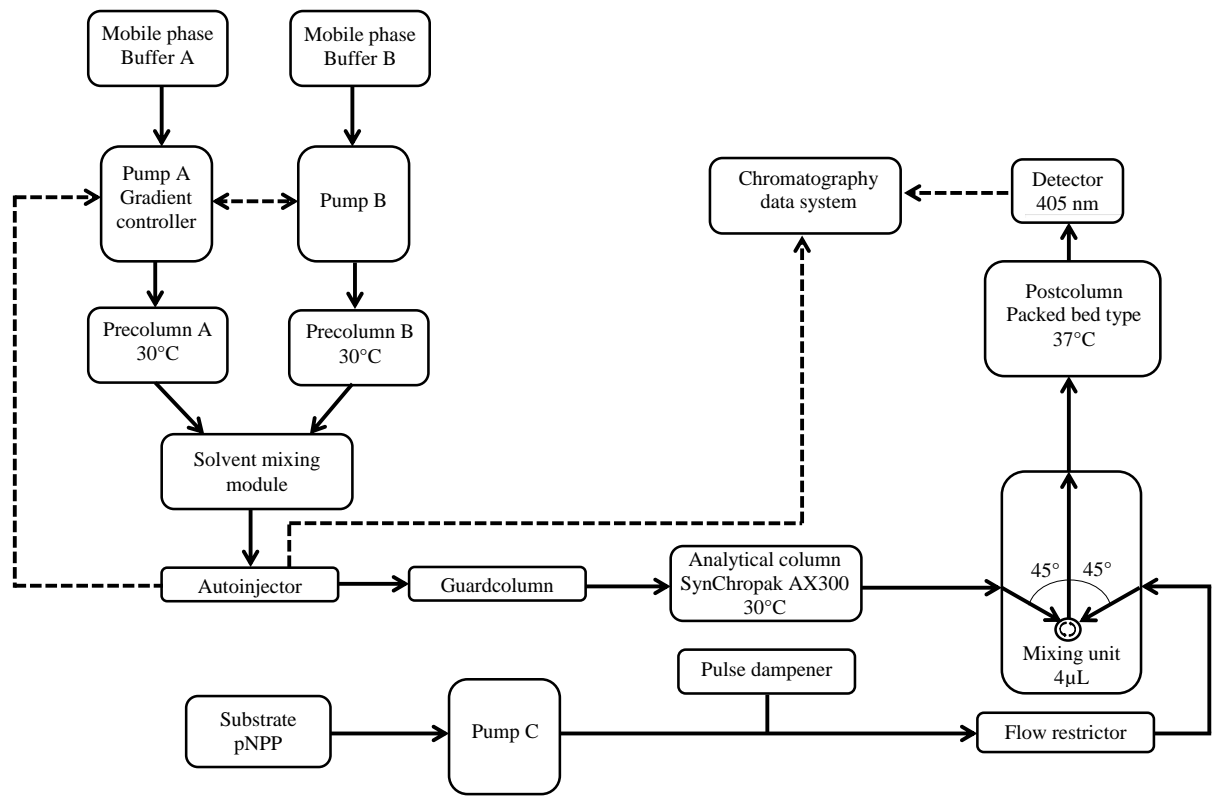

Figure 9. Schematic diagram of the HPLC assay for separation and quantification of ALP isoforms in serum. Solid lines indicate fluid connections and dotted lines indicate electrical connections. 


\section{Measurements of ALP activity and protein concentration}

Total ALP activity was measured by a kinetic assay in a 96-well microtitre plate format. In brief, a total volume of $300 \mu \mathrm{L}$ solution was added per well, containing 1.0 M DEA buffer ( $\mathrm{pH} 9.8$ ), $1.0 \mathrm{mM} \mathrm{MgCl} 2$ and $10 \mathrm{mM}$ pNPP. The time-dependent increase in absorbance at $405 \mathrm{~nm}$ (reflecting p-nitrophenol production) was determined on a Multiscan Spectrum microplate reader (Thermo Electron Corp., Vantaa, Finland). The relation between the enzymatic activity units kat and $\mathrm{U}$ is $1.0 \mu \mathrm{kat} / \mathrm{L}$ corresponds to $60 \mathrm{U} / \mathrm{L}$ [152]. Total protein concentrations were measured in a 96-well microtiter plate using the Pierce bicinchoninic acid protein assay kit (Thermo Scientific, Rockford, IL, USA) [153].

\section{Determination of glycosylation differences among the BALP isoforms}

It has been confirmed that both BALP and LALP are N-glycosylated, however, the number of glycosylation sites are not known [82]. In paper I, the different glycosylation patterns for the BALP isoforms (B/I, B1x, B1 and B2) were studied with several methods.

A native gel that separates proteins with respect to their size, shape and charge was used. The four BALP isoforms were separated on a Tris/Glycine polyacrylamide gel $4-12 \%$, and treated with neuraminidase to evaluate the effect how sialic acid residues influence migration of each isoform in the gel. After electrophoresis, the BALP isoforms were stained using 2-methyl-2-amino-1,3-propanediol buffer containing $\mathrm{MgCl}_{2}$, naphthyl phosphate and Variamine Blue RT salt (4-aminodiphenylamine diazonium sulphate).

Qualitative analysis of the glycosylation pattern for each isoform was performed with the DIG Glycan Differentiation kit (Roche Applied Science, Basel, Switzerland). This kit contains five digoxigenin labeled lectins: Datura stramonium agglutinin (DSA), Sambucus nigra agglutinin (SNA), Peanut agglutinin (PNA), Galanthus nivalis agglutinin (GNA), and Maackia amurensis agglutinin (MAA). DSA indicates galactose- $\beta(1-4)-\mathrm{N}$-acetylglucosamine; SNA, sialic acid terminally linked $\alpha(2-6)$ to galactose or $\mathrm{N}$-acetylgalactosamine; PNA, galactose- $\beta(1-3)-\mathrm{N}$-acetylgalactosamine; GNA terminal linked mannose; and MAA, sialic acid terminally linked $\alpha(2-3)$ to galactose. The BALP isoforms were denatured and applied to a SDS polyacrylamide gel and blotted to a nitrocellulose membrane. The membrane was thereafter incubated with the digoxigenin labeled lectins. The binding of each lectin to a 
particular carbohydrate structure was visualized with an ALP-labeled anti-digoxigenin antibody. Positive controls, with known carbohydrate side-chains, were used to test the specificity of the lectin bonding. Fetuin was used for DSA and MAA, carboxypeptidase Y for GNA, transferrin for SNA, and asialofetuin for PNA.

To determine if the linked carbohydrates were N-linked or O-linked, the N-Glycosidase F deglycosylation kit (Roche Applied Science) was used. The BALP isoforms were heatdenatured, treated with N-Glycosidase F (that cleaves N-linked glycan chains), and thereafter investigated with the DIG Glycan Differentiation kit with the same approach as for the untreated BALP isoforms. The isoforms were heat-denatured, separated on a SDS gel, blotted to a membrane and incubated with digoxigenin labeled lectins (DSA, SNA, PNA, GNA and MAA).

Differences in glycosylation patterns for the BALP isoforms were also determined by lectin precipitation. BALP isoforms were precipitated by incubation with DSA, PNA and SNA (glycan-specific lectins as described above). Duplicate aliquots of each BALP isoform were incubated with graded doses of each lectin. After precipitation, the samples were centrifuged and the remaining BALP isoform activity was measured in the supernatant.

\section{Surface plasmon resonance analysis}

In paper III, the interaction between collagen type I and ALP was studied with surface plasmon resonance (SPR). SPR analysis enables the detection and monitoring of biomolecular binding and can provide quantitative information about molecular specificity, affinity and interaction kinetics without need for labeling of the sample (Fig.10). The Biacore system exploits the SPR phenomenon to monitor the interaction between molecules in real-time [154]. One interacting molecule (the ligand) is immobilized on to the surface of a sensor chip, and the interacting molecule (the analyte) is passed over the surface at a constant flow. Binding of the analyte to the immobilized ligand generates a response which is proportional to the bound mass. 


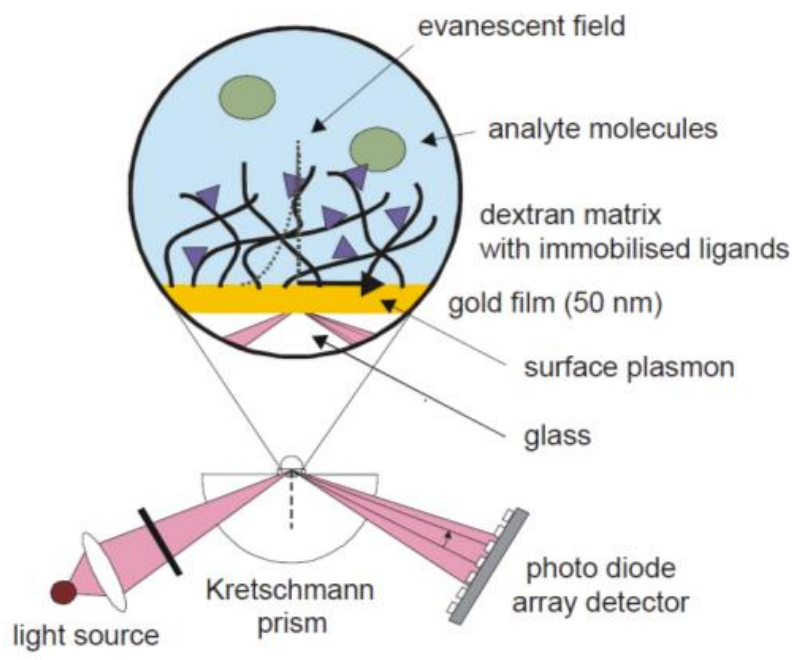

Figure 10. A SPR-based biosensor. The ligand (collagen type I) was immobilized in a dextran matrix attached to a gold surface, and the analyte molecule (ALP) was introduced in solution. Binding of the ligand to the analyte generates a shift in refractive index close to the surface, which will be detected by an optical method. The recorded response is proportional to the mass of bound analyte. Printed with permission [155].

A Biacore 3000 instrument (GE Healthcare Bio-Sciences AB) was used for SPR analysis of interactions between various ALP forms and collagen type I. All sensor chips and reagents were obtained from GE Healthcare Bio-Sciences AB. HEPES-buffered saline, $\mathrm{pH}$ 7.4, was used as running buffer and the flow rate was $10 \mu \mathrm{L} / \mathrm{min}$. Human collagen type I was immobilized on a CM5 sensor chip using conventional carbodiimide coupling, where injection of an aqueous mixture ethyldimethylaminopropylcarbodiimide (EDC) and $\mathrm{N}$ hydroxysuccinimide (NHS) for 7 min was followed by coupling of collagen ( $1 \mu \mathrm{M}$ in $10 \mathrm{mM}$ sodium acetate, $\mathrm{pH}$ 5.0, $7 \mathrm{~min}$ ) and deactivation of remaining active esters with ethanolamine ( $\mathrm{pH} \mathrm{8.5,} 7 \mathrm{~min}$ ). Prior to immobilization, the negative charge of the surface was reduced by injecting EDC/NHS (7 min) promptly followed by ethanolamine $(7 \mathrm{~min})$. This procedure was repeated once. A reference flow cell was prepared by treating the surface as above, with the exception of omitting the collagen coupling step.

ALP samples were diluted in HBS-N to a final ALP concentration of $1 \mu \mathrm{M}$. For interaction analysis, each ALP preparation was injected during $5 \mathrm{~min}$, followed by efficient 
regeneration with two 1 min pulses of $10 \mathrm{mM}$ glycin- $\mathrm{HCl} \mathrm{pH}$ 1.5. Each flow cell was used for two sequences of ALP injections (sequence: BALP, LALP, PALP, E. coli ALP, heatinactivated BALP, neuraminidase-treated BALP, heat-inactivated and neuraminidase-treated BALP, BALP isoform B1, BALP isoform B2). Five different flow cells with immobilized collagen were used in total.

After reference subtraction, signals $5 \mathrm{~s}$ before the end of each ALP injection were used as a measure of binding. These values were normalized with respect to the collagen immobilization levels in the different flow cells, assuming linearity in binding in this concentration range.

For affinity analysis, a sensor chip with immobilized collagen type I and a reference flow cell was prepared as described above. BALP samples diluted to $0.16-20 \mu \mathrm{M}$ were introduced sequentially at random order for $10 \mathrm{~min}$, followed by washing at $\mathrm{pH} 1.5$ as described above. After reference subtraction, the responses at the end of each injection was plotted as a function of BALP concentration and data was fitted to a 1:1 Langmuir binding model using the BIAevaluation 4.1 software (GE Healthcare Bio-Sciences AB) to obtain the equilibrium dissociation constant $\mathrm{Kd}$.

\section{Electrophoresis, blotting and detection of ALP and collagen type I interactions}

In paper III, the interaction between ALP and collagen type I was studied by blotting of ALP to a membrane and binding of collagen was detected with antibodies. Human BALP, LALP, PALP, and E. coli ALP were separated on a Tris/Glycine polyacrylamide gel 4-12\% under native conditions. After electrophoresis, half of the gel was stained for ALP activity using 2methyl-2-amino-1,3-propanediol buffer at $\mathrm{pH} 10.3$ containing $\mathrm{MgCl}_{2}$, naphthyl phosphate and Variamine Blue RT salt. From the other half of the gel, the various ALP forms were transferred to a polyvinylidene difluoride (PVDF) membrane (Bio-Rad Laboratories AB, Solna, Sweden) and stained with Ponceau S (Bio-Rad Laboratories AB) to ensure successful transfer. After incubation in blocking solution, the membrane was incubated with $1 \mu \mathrm{M}$ human collagen type I overnight at $4^{\circ} \mathrm{C}$. The membrane was subsequently incubated with a polyclonal antibody against human collagen type I (Abcam plc, Cambridge, UK) for 2 hours, diluted 1:3000 in blocking solution. Bound collagen were detected using HRP-conjugated streptavidin (GE Healthcare Bio-Sciences AB, Uppsala, Sweden) diluted 1:20000, followed 
by an enhanced chemiluminescent detection system (ECL plus; GE Healthcare Bio-Sciences $\mathrm{AB})$.

\section{Kinetic measurements}

\section{Paper I}

The catalytic properties were investigated for the BALP isoforms B/I, B1x, B1 and B2, in relation to the three suggested endogenous substrates PPi, PLP and PEA at physiological pH 7.4, and the synthetic substrate pNPP at $\mathrm{pH} 9.8$ and 7.4. Two human recombinant TNALP isoforms, TNALP-flag and SALP-FcD ${ }_{10}$, were analyzed in the same manner.

Purified BALP isoforms were diluted to suitable concentrations in a Tris buffer, $\mathrm{pH} 8.5$, containing $\mathrm{NaHCO}_{3}$ and zinc acetate [83]. Kinetic properties were evaluated using the substrate pNPP in DEA buffer containing $\mathrm{MgCl}_{2}$ and zinc acetate at $\mathrm{pH} 7.4$ and 9.8 and the three substrates PPi, PLP, and PEA in a Tris buffer, $\mathrm{pH} 7.4, \mathrm{MgCl}_{2}$ and zinc acetate. For pNPP, at pH 7.4 and 9.8, the absorbance was measured continuously for 5 and $10 \mathrm{~min}$, respectively. For the other substrates, the amount of free inorganic phosphate was determined after $60 \mathrm{~min}$ for $\mathrm{PP}_{\mathrm{i}}, 120 \mathrm{~min}$ for PLP and 48 hours for PEA [156]. The used concentrations for $\mathrm{pNPP}$, at $\mathrm{pH} 9.8$ and 7.4, were 0.1-10 mM, and for PPi and PLP, 2-10 mM, and for PEA 10-50 mM. The kinetic parameters, maximum reaction velocity $\left(\mathrm{V}_{\max }\right)$, Michaelis constant $\left(\mathrm{K}_{\mathrm{M}}\right)$, and the catalytic rate constant $\left(\mathrm{k}_{\mathrm{cat}}\right)$, were determined from a Hanes-Wolf plot where the substrate concentration was plotted against the substrate concentration divided with reaction velocity.

To study the effects of terminal sialic acid residues, each BALP isoform was treated with neuraminidase for 2 hours at $37^{\circ} \mathrm{C}$. The kinetic properties were assessed in the same approach as for untreated BALP isoforms.

The kinetic properties for the recombinant TNALP-flag and $\mathrm{sALP}-\mathrm{FcD}_{10}$ were determined by the same methods as for the isoforms.

\section{Paper IV}

In paper IV, the kinetic properties were evaluated for both BALP and TRAP using the endogenous substrates for BALP (i.e., PPi and PLP), as well as the synthetic substrate pNPP. All kinetic measurements were performed at the $\mathrm{pH}$ optima for each enzyme. The kinetic 
properties for TRAP were determined in a sodium acetate buffer, $\mathrm{pH} 5.8$, with $\mathrm{KCl}$, Triton $\mathrm{X}$ 100, disodium tartrate, ascorbic acid, and $\mathrm{Fe}\left(\mathrm{NH}_{4}\right)_{2}\left(\mathrm{SO}_{4}\right)$ (TRAP-buffer). The kinetic measurements of BALP were carried out in a $\left(\mathrm{NH}_{4}\right)_{2} \mathrm{CO}_{3}$ buffer, $\mathrm{pH}$ 8.5, with $\mathrm{MgCl}_{2}$ and zinc acetate (ALP-buffer). TRAP was diluted in TRAP-buffer to a final concentration of 0.03 $\mathrm{ng} / \mu \mathrm{L}$ for the measurements with $\mathrm{pNPP}$ and PPi, and $0.3 \mathrm{ng} / \mu \mathrm{L}$ for PLP. BALP was diluted in ALP-buffer to a final concentration of $0.04 \mu \mathrm{g} / \mu \mathrm{L}$ for all three substrates. All measurements were carried out in 96 -well plates and incubated in $37^{\circ} \mathrm{C}$ for $30 \mathrm{~min}$. For the kinetic measurements, $25 \mu \mathrm{L}$ of the substrate was added to a final concentration of $0.05 \mathrm{mM}$ to 10 $\mathrm{mM}$, together with $25 \mu \mathrm{L}$ TRAP or BALP solution, and $50 \mu \mathrm{L}$ buffer (TRAP- or ALP-buffer). After $30 \mathrm{~min}, 50 \mu \mathrm{L}$ stop solution was added to each sample, $0.5 \mathrm{M} \mathrm{NaOH}$ for the pNPP reaction and $0.2 \mathrm{M} \mathrm{Na}_{2} \mathrm{MoO}_{4}$ for PPi and PLP. For pNPP, the amount of formed pnitrophenol was measured by absorbance at $405 \mathrm{~nm}$, and for PPi and PLP the amount of liberated free phosphate was determined using the Biomol Green Reagent (Enzo Life Sciences Inc., Farmingdale, NY, USA).

The kinetic parameters, maximum reaction velocity $\left(\mathrm{V}_{\max }\right)$ and the Michaelis constant $\left(\mathrm{K}_{\mathrm{m}}\right)$, were determined from a Lineweaver-Burk plot where the substrate concentration was plotted against the specific enzyme activity.

\section{ALP from tissues and organs}

\section{Paper II}

In paper II, tissue-derived ALPs from mice were characterized. ALP was extracted from liver, kidney, intestine, and bone from vertebra, femur and calvaria. Tissues and organs were obtained from $20 \mathrm{BALB} / \mathrm{c}$ WT female mice, 7 to 9 weeks old, divided into four groups (one group contained the same organ from five mice). A separate group of mouse intestines, isolated in 7 segments in a total from 8 WT mice, were also collected and ingesta/feces washed out with PBS (Fig. 11). 


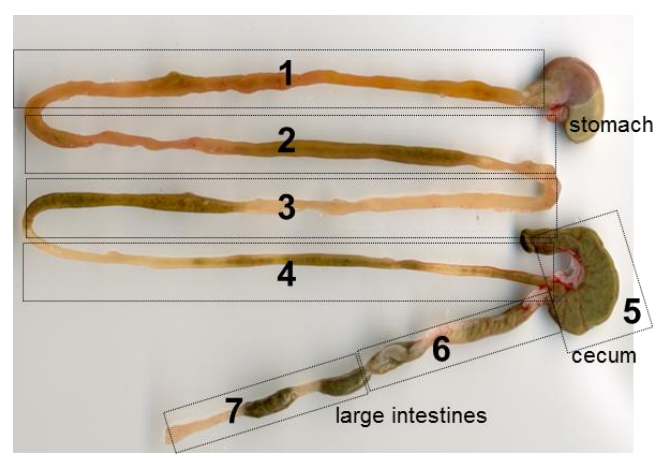

Figure 11. Intestine of WT mouse. Segment 1 contains the major part of duodenum; segments 2 and 3 are jejunum; segment 4 is ileum; segment 5 is cecum; segments 6 and 7 contains colon. (Printed with permission, Paper II).

Before extraction of ALP, the different tissue/organs were rinsed with PBS at $4^{\circ} \mathrm{C}$ until no visible blood remained. ALP was extracted in isotonic saline with $0.1 \%$ Triton X-100, $1 \mathrm{mM}$ benzamidine, $0.01 \mathrm{mg} / \mathrm{mL}$ phenylmethylsulfonyl fluoride and $0.02 \%$ sodium azide for 72 hours and centrifuged at $4000 \mathrm{~g}$ for $15 \mathrm{~min}$.

GPI-PLD, approximately $2000 \mathrm{U} / \mathrm{mL}$, was added to cleave ALP from insoluble membrane fragments to a final concentration of $25 \%$ together with $0.01 \%$ NP-40 and $5 \mu \mathrm{M}$ zinc acetate and incubated for 16 hours at $37^{\circ} \mathrm{C}$ with constant shaking. To separate the anchorless ALP from anchor-intact ALP, the preparation was incubated 1:1 with $20 \mathrm{mM}$ Tris, $0.2 \mathrm{mM} \mathrm{MgCl} 2,20 \mu \mathrm{M}$ zinc acetate and $4 \%$ Triton $\mathrm{X}-114, \mathrm{pH} 8.3$, for $30 \mathrm{~min}$ in a $37^{\circ} \mathrm{C}$ water bath and centrifuged at $1500 \mathrm{~g}$ for $10 \mathrm{~min}$ to separate the two phases. The upper phase containing anchorless ALP was collected and stored at $-70^{\circ} \mathrm{C}$ until analysis.

For determination of ALP isozymes and isoforms, sera from ALP KO mouse strains (corresponding protein name) were assessed by HPLC: i.e., $\mathrm{Alpl}^{+/+}, \mathrm{Alpl}^{+/-}$and $\mathrm{Alpl}^{{ }^{\prime-}}$ (TNALP); $A k p^{+/+}$and $A k p 3^{-/-}$(dIALP); and $\mathrm{Alpi}^{+/+}$and $\mathrm{Alpi}^{{ }^{-/}}$(gIALP). Commercially available serum preparations, pooled from mixed strains of WT mice (Sigma-Aldrich), were also assessed.

\section{ALP histochemical staining, Northern and Western blot analyses}

For histochemical staining, liver tissues from four WT mice strains and from ApoE-TNALP Tg (+) mice (used as positive control) were collected. ALP histochemical staining was processed by a previously described method [86]. In brief, mouse liver tissues were fixed with $10 \%$ formalin in PBS at $4^{\circ} \mathrm{C}$ for 48 hours, washed with increasing concentrations of sucrose 
in $\operatorname{PBS}(10 \%, 15 \%$ and $20 \%)$ at $4^{\circ} \mathrm{C}$ for 48 hours, and embedded in optimal cutting temperature compound. Tissue blocks were stored at $-80^{\circ} \mathrm{C}$ until sectioning. Twelve to sixteen micrometer sections were cut and stained for ALP activity. Pictures were taken by a Nikon TE300 microscope (Nikon, Melville, NY, USA)

Total RNA for Northern blot analysis was extracted from WT mouse liver and kidney tissues and subjected to Northern blot hybridization as previously described [157]. To detect mouse TNALP mRNA, $1.1 \mathrm{~kb}$ cDNA fragment from $3^{\prime}$ region of mouse TNALP cDNA NM_007431) was used as a probe, while a probe of mouse L32 ribosomal protein was used as standard.

Protein samples for Western blot analysis were extracted from WT mouse liver and kidney tissues and subjected to SDS PAGE by standard methods. The blotted membrane was processed for immunostaining as reported elsewhere [157]. Mouse and human TNALP were detected with rat anti-TNALP antibody (R\&D Systems, Minneapolis, MN, USA), and a $\beta$-actin antibody (Santa Cruz Biotechnology, Santa Cruz, CA, USA) was used for control purposes.

\section{Paper IV}

\section{Analysis of mRNA expression}

Mouse bones were disrupted and homogenized using a TissueLyser LT (Qiagen, Hilden, Germany). Total RNA was isolated with the RNeasy Plus Mini kit (Qiagen) according to the manufacturer's protocol, followed by quantification using a ND-1000 NanoDrop spectrophotometer (Thermo Fisher Scientific, Vantaa, Finland). The Super Script III kit (Invitrogen, Carlsbad, CA, USA) was used according to the manufacturer's protocol to prepare cDNA. RT-qPCR was performed with $12.5 \mathrm{ng}$ cDNA amplified in doublets using the iQ SYBR Green Supermix, and CFX96 Real time System (Bio-Rad Laboratories AB) in $10 \mu 1$ containing $200 \mathrm{nM}$ forward and reverse primers (CyberGene AB, Solna, Sweden) under the following conditions: $95^{\circ} \mathrm{C}(1 \mathrm{~min})$ plus 35 cycles with denaturation at $92^{\circ} \mathrm{C}(10 \mathrm{~s})$, annealing and elongation at $60^{\circ} \mathrm{C}(30 \mathrm{~s})$. Melting curves were generated using the conditions: $95^{\circ} \mathrm{C}(10$ s) followed by increase of $0.5^{\circ} \mathrm{C}$ every $5 \mathrm{~s}$ from $65^{\circ} \mathrm{C}$ to $95^{\circ} \mathrm{C}$. The mouse $\mathrm{Hprt}$ and $\beta$-actin genes were used as housekeeping controls. Results were analyzed using the Bio-Rad CFX manager 2.0 software (Bio-Rad Laboratories AB). 


\section{Immunohistochemical staining}

Humerus bones from 11 day-old mice were fixed in $4 \%$ paraformaldehyde and decalcified in $20 \%$ formic acid for 48 hours followed by embedding in paraffin and longitudinally sectioned to $4 \mu \mathrm{m}$ thick sections. The sections were then transferred to SuperFrost ${ }^{\circledR}$ glass slides (Menzel-Gläser, Braunschweig, Germany) and deparaffinized and rehydrated. To block endogenous peroxidase activity, each section was treated with $3 \% \mathrm{H}_{2} \mathrm{O}_{2}$ for 5 min at room temperature and after washing with PBS, nonspecific staining was prevented by treatment with 15\% normal goat serum (Dako Denmark A/S, Glostrup, Denmark) in PBS for 30 min at room temperature. Immunostaining for TRAP was performed using a polyclonal rabbit antibody [158] at a dilution of 1:1600 in PBS, incubated overnight at $4^{\circ} \mathrm{C}$. After washing in PBS, each section was incubated with biotin-conjugated goat anti-rabbit antibody 1:800 (Dako Denmark A/S), followed by development using avidin-conjugated horseradish peroxidase using the VECTASTAIN Elite ABC Kit (Vector Laboratories, Inc., Burlingame, CA, USA). Slides were counterstained with Mayer's hematoxylin prior to mounting.

\section{Dephosphorylation of OPN by BALP, IALP and TRAP}

OPN is a highly phosphorylated protein. In paper IV, OPN from bovine milk was dephosphorylated with BALP, IALP and TRAP in order to investigate the dephosphorylating properties of these enzymes.

Fully phosphorylated OPN, $10 \mu \mathrm{g}$, was incubated with $5 \mathrm{mU}$ TRAP, $20 \mathrm{mU}$ BALP or $20 \mathrm{mU}$ IALP at $37^{\circ} \mathrm{C}$ in siliconized Eppendorf tubes. Units of enzyme activity refer to pNPP equivalents. Dephosphorylation with TRAP was carried out in a buffer containing $0.1 \mathrm{M}$ sodium acetate at $\mathrm{pH} 5.0,0.15 \mathrm{M} \mathrm{KCl}, 10 \mathrm{mM}$ disodium tartrate, $1 \mathrm{mM}$ ascorbic acid and 0.1 $\mathrm{mM} \mathrm{Fe}\left(\mathrm{NH}_{4}\right)_{2}\left(\mathrm{SO}_{4}\right)$, and stopped at different time points, $0-24$ hours, with $10 \mathrm{mM}$ $\mathrm{Na}_{2} \mathrm{MoO}_{4}$. Dephosphorylation with BALP and IALP was performed in a buffer containing $200 \mathrm{mM}\left(\mathrm{NH}_{4}\right)_{2} \mathrm{CO}_{3}$ at $\mathrm{pH} 8.5,2 \mathrm{mM} \mathrm{MgCl}{ }_{2}$ and $40 \mu \mathrm{M}$ zinc acetate, and stopped at different time points with $20 \mathrm{mM}$ EDTA. Liberated phosphate was determined at each time point by addition of $100 \mu \mathrm{L}$ of Biomol Green Reagent to $20 \mu \mathrm{L}$ dephosphorylated OPN and incubated for $20 \mathrm{~min}$ at room temperature.

Dephosphorylation of OPN was also investigated with different quantities of TRAP $(0.5,1.25,2.5$ and $5 \mathrm{mU})$, BALP and $\operatorname{IALP}(5,10,20$ and $40 \mathrm{mU})$. The amount of liberated free phosphate was measured with Biomol Green Reagent after incubation for 24 hours. 


\section{In vitro mineralization}

In paper IV, in vitro mineralization was studied with and without inhibiting OPN. Human osteoblast-like SaOS-2 cells were grown in 96-well black-walled plates in Dulbecco's modified Eagle's medium - low glucose, supplemented with $1 \%$ fetal calf serum, $1 \%$ penicillin/streptomycin, $40 \mathrm{U} / \mathrm{mL}$ nystatin and incubated at $37^{\circ} \mathrm{C}$ with $95 \%$ humidity and $5 \%$ $\mathrm{CO}_{2}$. Mineralization was initiated 24 hours after plating out the cells. Medium was replaced with fresh medium supplemented with $2 \mathrm{mM} \beta$-glycerophosphate and $50 \mu \mathrm{g} / \mathrm{mL}$ ascorbic acid in order to initiate mineralization. Fully phosphorylated OPN and partly dephosphorylated OPN (by BALP or TRAP) were added to a final concentration of $0.1 \mu \mathrm{g} / \mathrm{mL}$. Cells were cultured for 5 days after initiation of mineralization and media was changed on day 2 and day 4.

The amount of mineral in the cell culture was quantified using the OsteoImage Mineralization Assay (Lonza Walkersville, Inc., Walkersville, MD, USA), which specifically binds to HA nodules. This assay is, unlike typical histochemical methods such as von Kossa and Alizarin Red, HA-specific [159, 160]. The OsteoImage Mineralization Assay is an in vitro assay that can quantitate bone cell mineralization and is based on the specific binding of the fluorescent OsteoImage staining reagent to the HA portion of the bone-like nodules deposited by cells (Fig. 12). Medium was removed 5 days after the initiation of mineralization and the cells were fixed with $99 \%$ ethanol and incubated with the fluorescent OsteoImage reagent. Fluorescence was determined using a fluorescent microplate reader (Fluoroskan Ascent FL, Thermo Fisher Scientific) with excitation/emission set on 485/538 nm. The measured fluorescence is proportional to the amount of HA present in the culture.

Images of mineralizing cells were captured with a 10x objective (NA 0.3) on a Zeiss Axio Observer Z1 with an AxioCam MRm camera (Carl Zeiss MicroImaging, Thornwood, NY, USA ) and excitation/emission set on 485/538 nm. Images were captured of cells grown; i) without $\beta$-glycerophosphate and ascorbic acid, ii) with $2 \mathrm{mM} \beta$-glycerophosphate and 50 $\mu \mathrm{g} / \mathrm{mL}$ ascorbic acid, iii) and with $2 \mathrm{mM} \beta$-glycerophosphate, $50 \mu \mathrm{g} / \mathrm{mL}$ ascorbic acid and OPN (fully phosphorylated). 

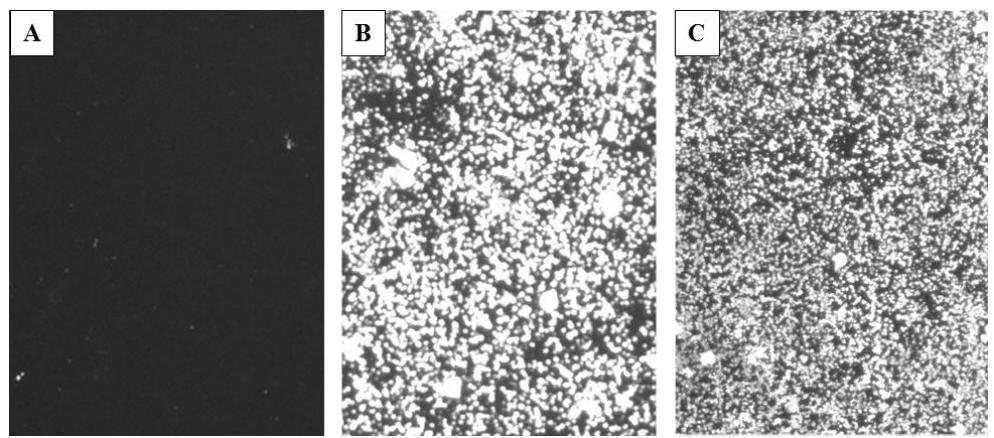

Figure 12. Osteoblast-like SaOS-2 cells cultured for 10 days after initiation of mineralization. Cells were stained with the OsteoImage Mineralization Assay, which specifically detects the HA portion of bone-like nodules deposited by cells.
A. Cells without mineralization medium.
B. Cells with mineralization medium but without OPN.
C. Cells with mineralization medium and $0.3 \mu \mathrm{g} / \mathrm{mL}$ OPN (fully phosphorylated).

\section{Statistical analysis}

In paper III, multiple comparisons were performed by one-way analysis of variance (ANOVA) with Tukey's test for post hoc analysis, and intergroup comparisons were done by Student's $t$-test. A $p$ value of $<0.05$ was considered statistically significant for all analyses. Values are presented as mean \pm standard error of the mean (SEM).

In paper IV, all results were presented as mean \pm standard deviation (SD). Statistical analyses were performed using unpaired two-tailed Student's t-test for comparisons between two groups, and ANOVA was used to test for differences involving more than two groups. For all statistical tests, a difference was considered significant at $\mathrm{p}<0.05$. 


\section{RESULTS AND DISCUSSIONS}

\section{Paper I}

In paper I, the BALP isoforms were investigated with a special focus on glycosylation patterns and catalytic properties towards the three presumptive physiological substrates (i.e., PPi, PLP, and PEA) [117, 123]. Patients with life-threatening HPP can be treated with a recombinant TNALP targeted to bone, here named $\mathrm{SALP}-\mathrm{FcD}_{10}$. This recombinant TNALP and another commonly used recombinant form, TNALP-flag, was also investigated in relation to PPi, PLP and PEA.

\section{Kinetic measurements}

Significantly different catalytic properties were found among the purified human BALP isoforms. B2 had higher activity for both PPi and PLP, i.e., $\mathrm{k}_{\mathrm{cat}} / \mathrm{K}_{\mathrm{M}}$ was 38 -fold higher for B2 in comparison with B1 with PPi, and 415-fold higher with PLP. The catalytic activity using PEA as substrate was barely detectable for all BALP isoforms. Activities for the recombinant forms, sALP-FcD 10 and TNALP-flag, were comparable with activities for the human BALP isoforms for all tested substrates. The activity, using PEA as a substrate, was next to nothing for both TNALP-flag and sALP-FcD 10 (Fig. 13).

\section{Glycosylation studies}

Qualitative glycosylation patterns of the denatured BALP isoforms were investigated with five different lectins (i.e., SNA, DSA, GNA, PNA, and MAA). SNA that indicates sialic acid, terminally linked $\alpha(2-6)$ to galactose or $\mathrm{N}$-acetylgalactosamine, and DSA that indicates galactose- $\beta(1-4)-N$-acetylglucosamine, had strong reactivity with $\mathrm{B} 1$ and $\mathrm{B} 1 \mathrm{x}$. GNA, that bind terminal linked mannose, showed reactivity with B/I and PNA that bind galactose- $\beta(1$ 3)-N-acetylgalactosamine, showed reactivity with B2. MAA that indicates sialic acid terminally linked $\alpha(2-3)$ to galactose did not bind to any of the BALP isoforms (Table 2).

After treatment with $\mathrm{N}$-Glycosidase $\mathrm{F}$ that cleaves all N-linked glycans, none of the lectins showed reactivity with any the BALP isoforms, which indicates that all of the 
demonstrated lectin binding capacities of denatured BALP isoforms were due to N-linked glycans.
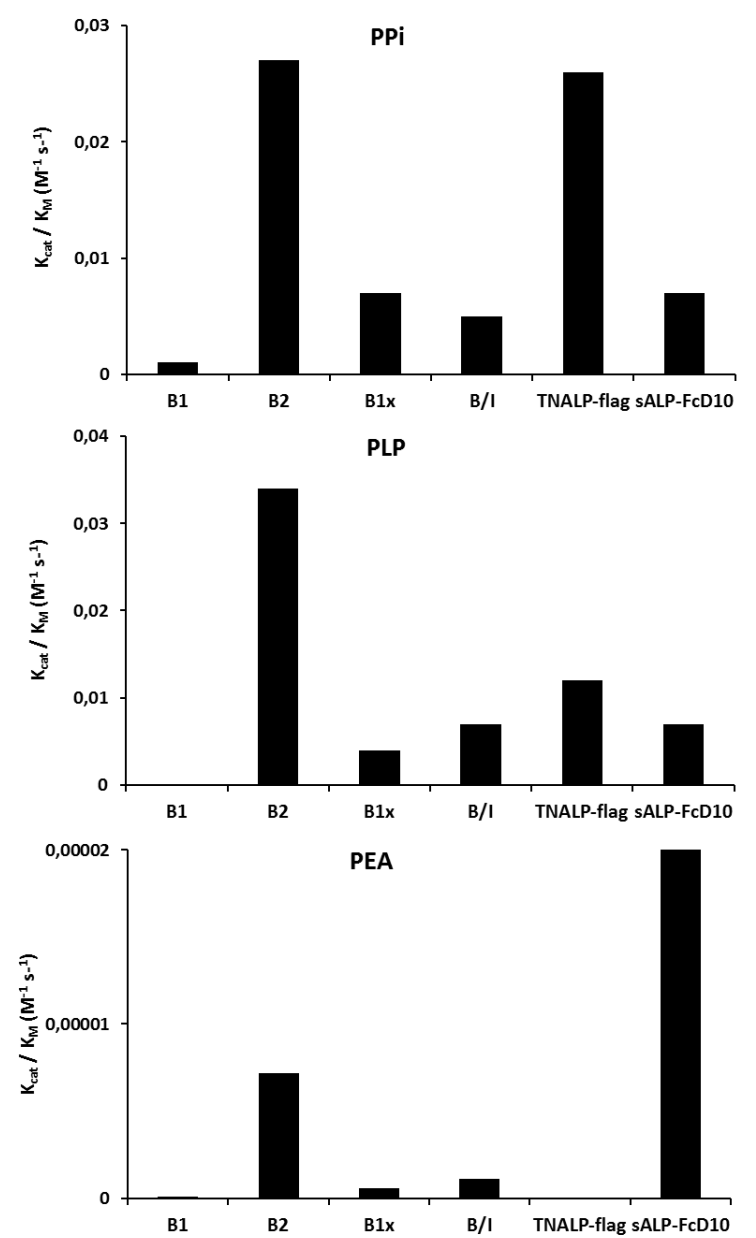

Figure 13. Kinetic properties for the BALP isoforms and the recombinant TNALPs, TNALPflag and sALP-FcD 10 , for PPi, PLP and PEA at $\mathrm{pH}$ 7.4. 
Table 2. Specific binding of different lectins to denatured BALP isoforms in order to characterize different patterns of glycosylation.

\begin{tabular}{|c|c|c|c|c|}
\hline \multirow[b]{2}{*}{ Lectins } & \multicolumn{4}{|c|}{ BALP isoforms } \\
\hline & B1 & $B 2$ & $B 1 x$ & $B / I$ \\
\hline DSA & +++ & - & +++ & - \\
\hline SNA & +++ & - & +++ & - \\
\hline PNA & - & $(+)$ & - & - \\
\hline GNA & - & - & - & + \\
\hline MAA & - & - & - & - \\
\hline
\end{tabular}

In paper I, we demonstrated significantly different catalytic properties among the BALP isoforms for the physiological substrates PPi and PLP, possibly due to glycosylation differences on the $\mathrm{N}$-linked glycans of the isoforms. Four of the 5 putative $\mathrm{N}$-glycosylations sites are located close to or within the active site of BALP and seems to play a specific role for the catalytic activity and is most likely the reason for the different kinetic properties among the isoforms [105]. All BALP isoforms showed extremely low activity with PEA. The $\mathrm{k}_{\mathrm{cat}} / \mathrm{K}_{\mathrm{M}}$ with PEA was about 10,000 times lower than for PPi and about 800-5000 times lower than for PLP. Our data suggests that PEA is not an endogenous substrate for the BALP isoforms or for the recombinant forms of TNALP. It has been hypothesized that PEA is an endogenous substrate for TNALP due to the elevated levels of PEA in HPP patients [141, 161]. Several different reasons for increased levels of PEA have been suggested; however, the metabolic pathway that leads to PEA accumulation remains elusive. Millán et al. [162] investigated patients with HPP and found that high urinary levels of PEA correlated inversely with LALP but not with BALP activity. This finding indicates that PEA could be a physiological substrate for LALP. Previous studies by Roberts et al. [163] showed that PHOSPHO1, which is upregulated in mineralizing cells, can catalyze PEA. Buchet et al. [127] suggested that significantly reduced PLP levels in the liver of TNALP-deficient mice may explain the increased levels of PEA. PLP is a cofactor for the enzyme Ophosphoethanolamine phosphor-lyase that transforms PEA to acetaldehyde, $\mathrm{Pi}$ and $\mathrm{NH}_{3}$ [164]. 
All these previous findings support our conclusion that PEA is not a substrate for BALP but possibly for some other ALP. The B2 isoform showed a 38-fold higher activity for PPi in comparison with B1. The activity of B2 is much higher in human serum than for B1, but the amount (protein concentration) of B2 is less than the amount of B1. The different reaction kinetics for the BALP isoforms could result in differences in their ability to regulate the inhibitory levels of PPi and the concentration of $\mathrm{Pi}$, thus the PPi/Pi ratio, needed for $\mathrm{HA}$ crystal growth.

\section{Paper II}

Mice are often used as an animal model to study bone and mineral metabolism, gastrointestinal physiology and other cellular and hormonal mechanisms in order to investigate and clarify human-related biological functions. However, little is known about the circulating ALPs in mice and their association with the human ALP isozymes and isoforms. In paper II, we characterized the ALP isozymes and isoforms in mouse tissues and serum.

\section{HPLC analysis of ALP from mouse and human serum}

Identical BALP isoforms (B/I, B1, and B2) were detected in mouse serum as in human serum (Fig. 14), and in addition, it was possible to detect the B1x bone isoform in mouse serum, which has only been detected in patients with chronic kidney disease and in human bone tissue $[111,112]$. Three LALP isoforms can normally be detected in human serum. A peak with ALP activity was detected with similar retention time as human LALP in mouse serum; however, subsequent experiments demonstrated that this peak was of intestinal origin (Alpi) and not of liver origin. 

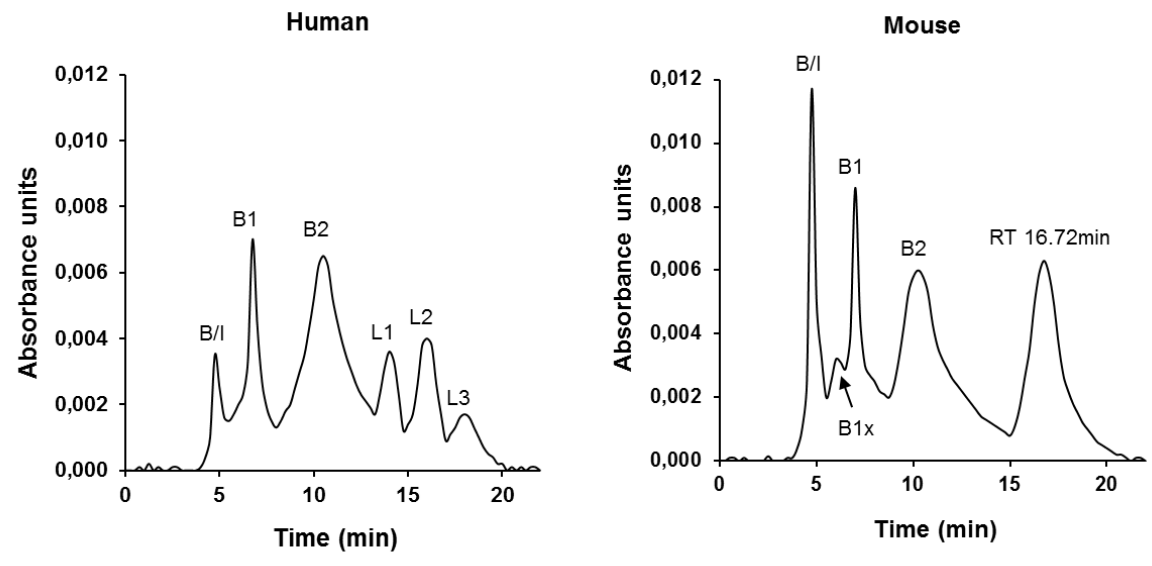

Figure 14. Chromatographic ALP profiles of human serum and WT mouse serum. A. Human serum: Total ALP 2.0 $\mu \mathrm{kat} / \mathrm{L}$. Peak identitet and retention times: B/I $4.88 \mathrm{~min}, \mathrm{~B} 16.92 \mathrm{~min}$, B2 $10.47 \mathrm{~min}$, L1 $13.92 \mathrm{~min}$, L2 16.05 and L3 $17.93 \mathrm{~min}$. B. Mouse serum: Total ALP 3.6 $\mu \mathrm{kat} / \mathrm{L}$. Peak identity and retention times: B/I $4.87 \mathrm{~min}, \mathrm{~B} 1 \mathrm{x} 5.95 \mathrm{~min}, \mathrm{~B} 17.10 \mathrm{~min}, \mathrm{~B} 210.28$ min and IALP (Alpi) $16.72 \mathrm{~min}$.

\section{ALP in mouse tissue extracts}

Significant amounts of ALP were extracted from all mouse tissues except from liver samples, which had remarkably low amounts of ALP activity (Fig. 15A). Analysis of liver tissue extracts from four WT mice strains, i.e., C57Bl/6, BALB/c, FVB/N and ICR, confirmed the low ALP activities. ALP histochemical staining of liver tissues from four WT mice strains showed no detectable ALP in the liver. Strong ALP activity was observed in the liver of ApoE-TNALP Tg (+) mice expressing human TNALP (used as positive control) (Fig. 15B).

Northern and Western blot analysis confirmed the results from the histochemical staining. The mouse TNALP gene was expressed at high levels in kidney and embryonic stem cells (used as positive control), while only trace amounts of mRNA were detected in the liver samples from each WT mice strain. Mouse TNALP was not detected significantly in liver samples from the four WT mice strains, while human TNALP was highly expressed in the liver from ApoE-TNALP Tg (+) mice and mouse TNALP was detected in normal kidney. In mouse intestine, ALP activity was found in all 7 intestinal segments but with very low activities in segments 6 and 7 (Fig. 15C and D). 
A

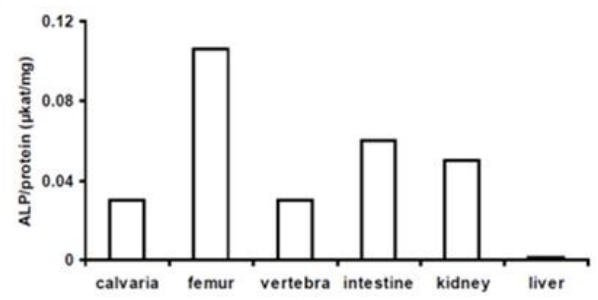

C

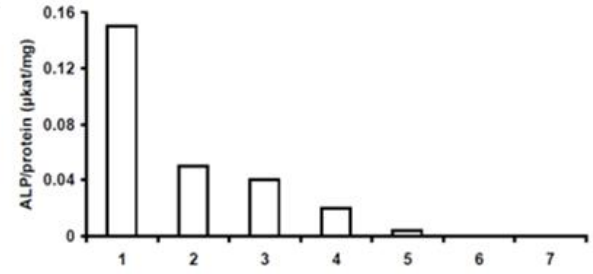

B

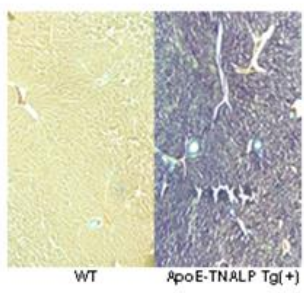

D

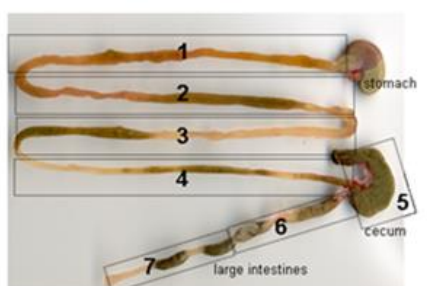

Figure 15. A. ALP activities in pooled tissue extracts from $20 \mathrm{WT}$ mice. B. ALP histochemical staining of liver tissues from one WT mouse (left) and ApoE-TNALP Tg (+) mouse expressing human TNALP under control of a liver-specific promoter (right). C. ALP activities in pooled tissue extracts from intestinal segments of 8 WT mice. D. Intestine of WT mouse. Segment 1 contains the major part of duodenum; segments 2 and 3 are jejunum; segment 4 is ileum; segment 5 is cecum; segments 6 and 7 contains colon.

HPLC analysis of the seven examined intestinal segments showed three different fractions in duodenum (segment 1), two early peaks and one later peak. Jejunum (segments 2 and 3) and ileum (segment 4) showed only the later peak (Fig 16). The later peak in these intestinal tissue extracts had the same retention time as the late peak appearing in the HPLC analysis of mouse serum, i.e., the gIALP isozyme. These results confirm that mice have more than one IALP isozyme and/or isoform originating from the Akp3 and Alpi genes. 

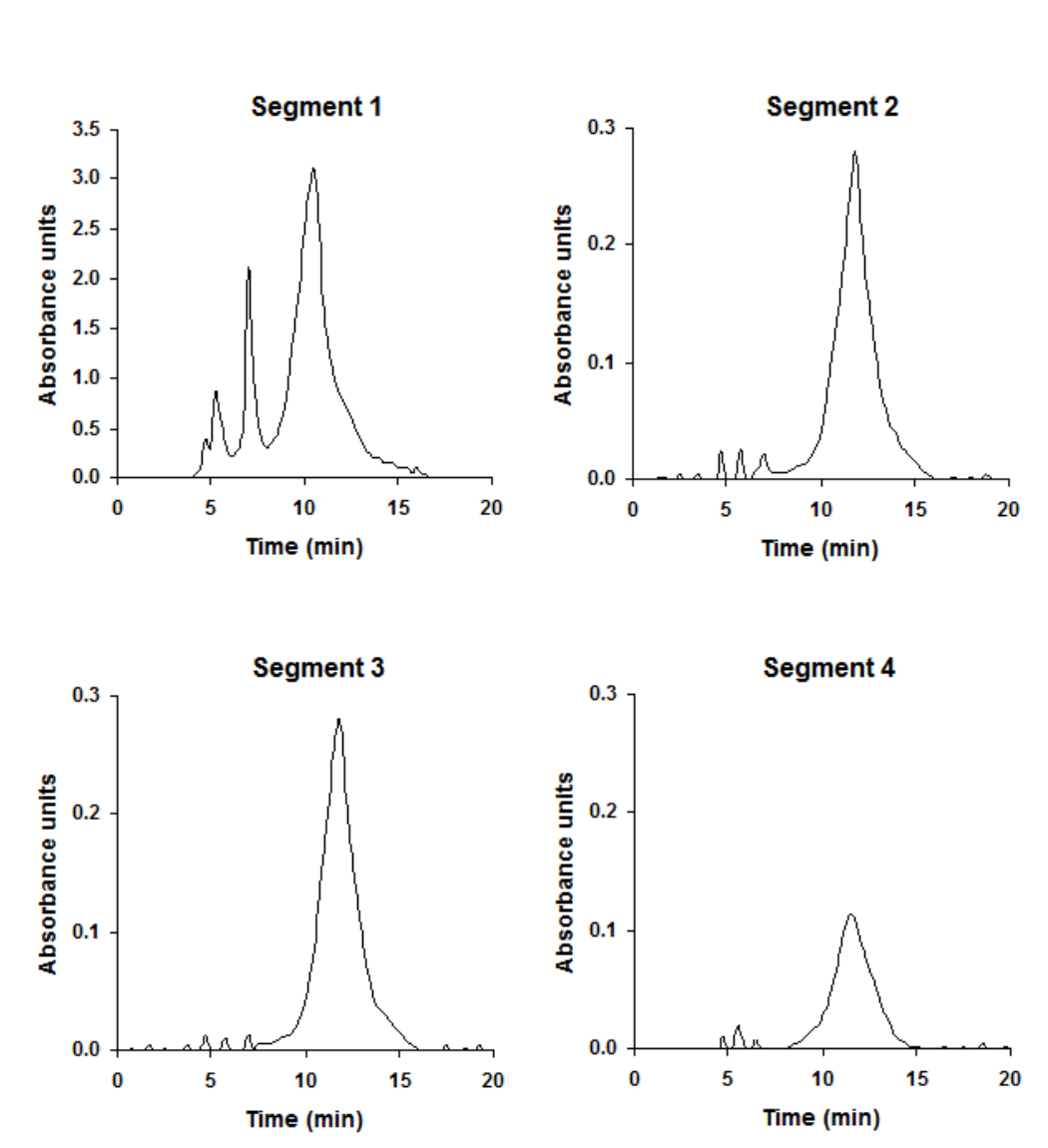

Figure 16. Chromatographic ALP profiles of tissue extracts from mouse intestinal segments. Total ALP activities and retention times are as follows: Segment 1 (duodenum): Total ALP $240 \mu \mathrm{kat} / \mathrm{L}, 5.33 \mathrm{~min}, 6.95 \mathrm{~min}$ and $10.40 \mathrm{~min}$. Segment 2 (jejunum): Total ALP $39.8 \mu \mathrm{kat} / \mathrm{L}$, $11.67 \mathrm{~min}$. Segment 3 (jejunum): Total ALP $20.90 \mu \mathrm{kat} / \mathrm{L}, 11.43 \mathrm{~min}$. Segment 4 (ileum): Total ALP $16.30 \mu \mathrm{kat} / \mathrm{L}, 11.62 \mathrm{~min}$.

The work in paper II demonstrates that mice have identical BALP isoforms (B/I, B1x, B1, and B2) in serum as previously reported for humans [84]. The B1x bone isoform, that previously only been detected in patients with chronic kidney disease and in human bone tissue [111, 112], is present in serum from all WT mice. In humans, the main sources of serum ALP are from bone and liver in approximately equal amounts. Despite numerous attempts with different extraction times and different WT mouse strains, we could not extract any significant amounts of ALP from liver tissue. Our results demonstrate that serum from WT 
mice consists mostly of BALP, including all four isoforms and both IALP isozymes, i.e., dIALP (Akp3) and gIALP (Alpi). These findings are important as it demonstrates that measuring ALP in mice is not informative when studying hepatocytes and liver function. The gene coding for TNALP in mice is named Alpl where 1 stand for liver ALP. We suggest, in this paper, that the name of the gene should be reconsidered since WT mouse hepatocytes have insignificant amounts of TNALP. Based on the work in paper II, we suggest the new nomenclature $A l p b$ for mice and $A L P B$ for humans, which would be more accurate.

\section{Paper III}

Coexpression of TNALP and collagen type I is found to be necessary for mineralization in bones and teeth, and both are specifically expressed in osteoblasts and odontoblasts, respectively $[31,165]$. Prior studies have mainly reported binding of various ALP isozymes to collagen type II [58, 63, 64, 102]. In paper III, we investigated the binding properties of human BALP to human collagen type I, the major structural component in the extracellular matrix of bone. Furthermore, we compared the binding properties of the two major TNALPs, BALP and LALP, the two major BALP isoforms B1 and B2, PALP and ALP from E. coli.

\section{Molecular interaction analysis by SPR}

BALP bound to the collagen-modified surface with a response of $272 \pm 29$ RU (Fig. 17A). In contrast, LALP, PALP and E. coli ALP had much weaker interactions with collagen type I, i.e., LALP, $28 \pm 3$ RU; PALP, $54 \pm 3$ RU; and E. coli ALP, $40 \pm 3$ RU. The protein-protein interaction between collagen type I and BALP was significantly stronger in comparison with the other ALP forms, $p<0.001$ (Fig. 17A). The human BALP isoform B2 bound significantly stronger to collagen type I, $254 \pm 10 \mathrm{RU}$, in comparison with the $\mathrm{B} 1$ isoform, $124 \pm 4 \mathrm{RU}, p<$ 0.001 (Fig. 17B). 

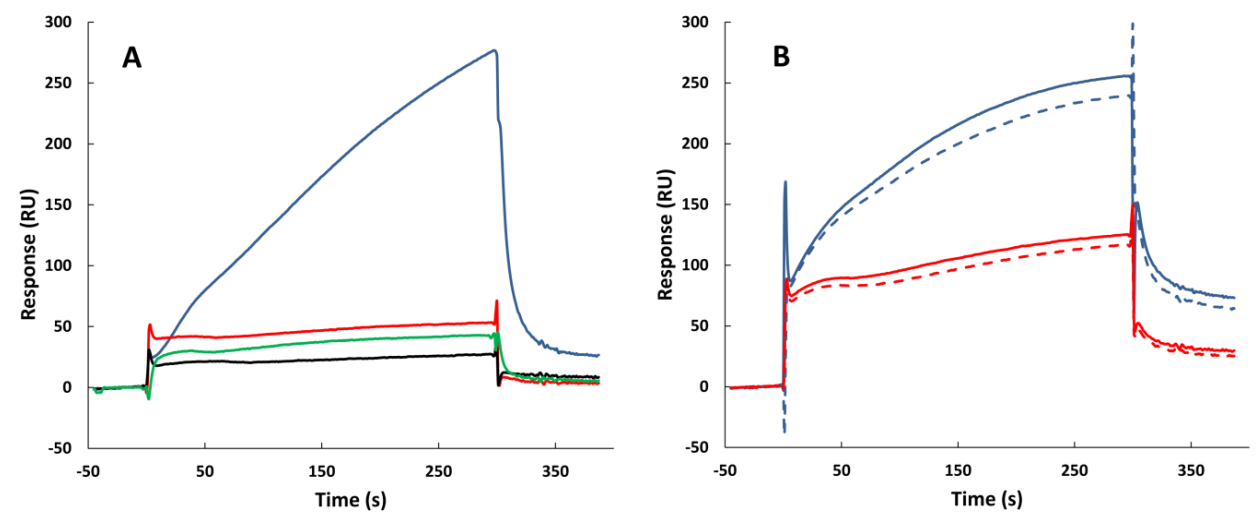

Figure 17. A. SPR sensorgrams showing human BALP (blue), LALP (black), PALP (red), and $E$. coli ALP (green) interacting with immobilized human collagen type I. Discontinuities at the start and end of each ALP injection are due to subtraction with data from a reference measurement where no collagen was present. Signals $5 \mathrm{~s}$ before the end of each injection were used as a measurement of binding. Values are normalized with respect to the collagen immobilization levels in the different flow cells. Mean \pm SEM values $(n=10)$ were: BALP, $272 \pm 29$ RU; LALP, $28 \pm 3$ RU; PALP, $54 \pm 3$ RU; and E. coli ALP, $40 \pm 3$ RU. The proteinprotein interaction between collagen type I and BALP was significantly stronger in comparison with the other ALP forms, $p<0.001$.

B. SPR sensorgrams showing human BALP isoforms B1 (red) and B2 (blue) interacting with immobilized human collagen type I. Solid lines correspond to the first injection of B1 and B2 in the sample sequence, while dashed lines are the same sample injected on the identical sensor chip after the surface had been subjected to eight other samples and 18 pulses of washing at $\mathrm{pH} 1.5$, indicating excellent stability of the binding properties of the immobilized collagen upon regeneration. Mean \pm SEM values $(n=10)$ were $124 \pm 4$ RU for B1 and $254 \pm$ 10 RU for B2. Significant differences were found between the binding affinities of B1 and B2 to human collagen type I, $p<0.001$.

The results from the SPR analysis was confirmed by blotting of the different ALPs to a PVDF membrane and incubation with human collagen type I. This revealed a protein-protein interaction between collagen type I and BALP, whereas no interactions were observed with LALP, PALP or E. coli ALP.

In paper III, we present evidence that glycosylation differences in human ALPs are of crucial importance for protein-protein interactions with collagen type I. Different binding affinities among the BALP isoforms may influence the mineral-collagen interface, mineralization kinetics and degree of bone matrix mineralization, which are important factors determining 
the material properties of bone. The results in this paper showed that BALP and its isoforms, known to be involved in mineralization, bound significantly stronger to collagen type I than other human ALPs expressed in non-mineralizing tissues and E. coli ALP. It has been suggested that the presence of a crown domain is prerequisite for collagen binding [101, 102]. LALP and PALP, both having a crown domain, showed weak binding to collagen but not weaker than E. coli ALP that is lacking the crown domain. BALP, together with its isoforms $\mathrm{B} 1$ and $\mathrm{B} 2$, and LALP are all coded by the same $A L P L$ gene and the amino acid composition of the proteins is identical. However, there are substantial differences in binding abilities. These differences must be attributed to individual glycosylation properties of the same TNALP protein core resulting in different affinities for collagen.

The isoform B2 has higher binding properties to collagen type I in comparison with B1 and, as shown in paper I, B2 has significantly higher enzymatic activity for PPi compared to B1. There are differences in the distribution of B1 and B2 at various skeletal sites. Trabecular bone has more of the B2 isoform compared with cortical bone. Trabecular bone is considered to have a higher remodeling rate compared with cortical bone [6] and isoform B2 is 35 times more effective in cleaving PPi into free phosphate compared with isoform B1. This results in higher concentrations of free phosphate necessary for HA formation, and less amounts of the potent mineralization inhibitor PPi facilitating the higher remodeling rate in trabecular bone.

\section{Paper IV}

A model to explain the differential roles of the two phosphatases BALP and TRAP is missing and their possible functional interplay remains to be explored. BALP and TRAP might substitute for each other as regulators of mineralization. In paper IV, we investigated the kinetic properties of TRAP towards the known endogenous substrates of BALP (i.e., PPi and PLP $[65,84])$, in order to explore the possible relevance of TRAP in skeletal mineralization. Furthermore, it was also investigated how BALP and TRAP can act as regulators of mineralization by dephosphorylating the mineralization inhibitor OPN. 


\section{Determination of kinetic properties for BALP and TRAP}

Both BALP and TRAP displayed catalytic activity for the three substrates PPi, PLP and pNPP (Table 3). The enzymatic activities at their respective $\mathrm{pH}$ optima for the used buffers (i.e., BALP pH 8.5; TRAP $\mathrm{pH}$ 5.8) were significantly higher for TRAP in comparison with BALP for all substrates, but were particularly pronounced for pNPP and PPi.

Table 3. Kinetic properties for the endogenous substrates (for BALP) PPi and PLP, and the synthetic substrate pNPP.

\begin{tabular}{l|ll}
\hline $\mathbf{V}_{\max }(\mathbf{m U} / \mathbf{m g})$ & & \\
$\mathrm{PPi}$ & $22000 \pm 2160$ & $30 \pm 13^{* *}$ \\
$\mathrm{PLP}$ & $390 \pm 7$ & $90 \pm 16^{*}$ \\
$\mathrm{pNPP}$ & $774000 \pm 160000$ & $180 \pm 9^{*}$ \\
& & \\
\hline
\end{tabular}

Results are expressed as mean \pm SD of three independent experiments. $* \mathrm{p}<0.05, * * \mathrm{p}<0.005$

\section{Dephosphorylation of OPN by BALP and TRAP}

OPN purified from bovine milk contain, on average, 28 phosphorylations on 27 serine residues and 1 threonine residue [166]. OPN treated with 5 mU TRAP was completely dephosphorylated after 24 hours, whereas $20 \mathrm{mU}$ BALP could only remove 10 phosphates (36\%) after 24 hours and $20 \mathrm{mU}$ of IALP could remove 20 phosphates (71\%) (Fig. 18 upper). Raising the amount of BALP and IALP to $40 \mathrm{mU}$, did not increase the amount of liberated free phosphate from OPN at 24 hours (Fig. 18 lower). 


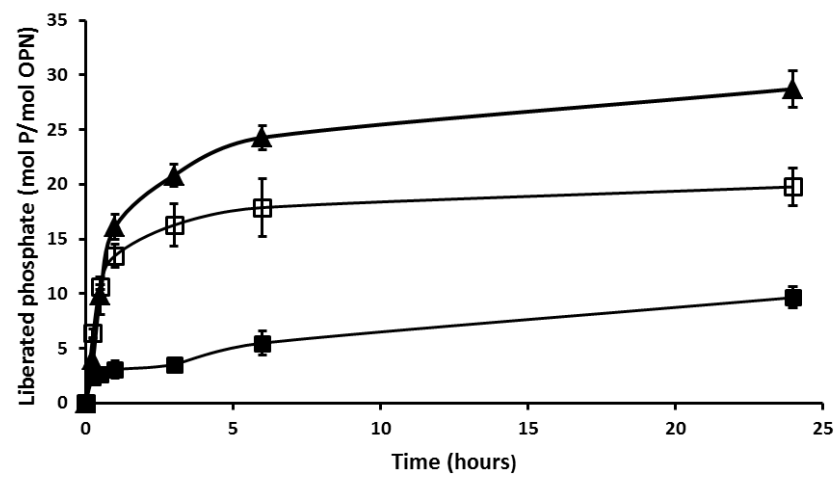

\begin{tabular}{l|lll}
\hline $\begin{array}{l}\text { Time } \\
\text { points }\end{array}$ & $\begin{array}{l}\text { TRAP vs. BALP } \\
(\boldsymbol{p} \text { value })\end{array}$ & $\begin{array}{l}\text { TRAP vs. IALP } \\
(\boldsymbol{p} \text { value })\end{array}$ & $\begin{array}{l}\text { BALP vs. IALP } \\
(\boldsymbol{p} \text { value })\end{array}$ \\
\hline $15 \mathrm{~min}$ & $\mathrm{NS}$ & $\mathrm{NS}$ & $<0.005$ \\
$30 \mathrm{~min}$ & $<0.05$ & $\mathrm{NS}$ & $<0.005$ \\
$1 \mathrm{~h}$ & $<0.01$ & $\mathrm{NS}$ & $<0.005$ \\
$3 \mathrm{~h}$ & $<0.005$ & $\mathrm{NS}$ & $<0.05$ \\
$6 \mathrm{~h}$ & $<0.005$ & $\mathrm{NS}$ & $<0.05$ \\
$24 \mathrm{~h}$ & $<0.01$ & $<0.05$ & $<0.005$ \\
\hline
\end{tabular}

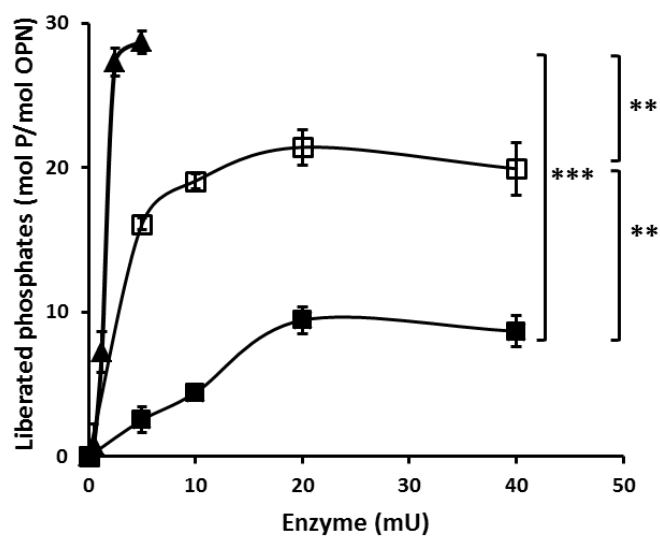

Figure 18. Upper. Dephosphorylation of OPN by TRAP, BALP and IALP with $5 \mathrm{mU}$ of

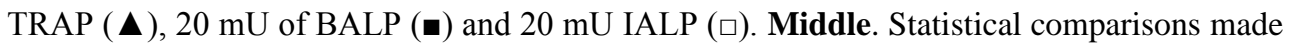
between TRAP, BALP and IALP at each time point (NS = not significant). Lower. Differences between TRAP, BALP and IALP regarding the dephosphorylation efficiency on OPN. TRAP ( $\boldsymbol{\Delta})$, BALP ( $\mathbf{\square})$, and IALP $(\square)$. Statistical comparisons were made between the maximum values of liberated free phosphate for each enzyme, i.e., TRAP, 5 mU; BALP, 20 $\mathrm{mU}$; and IALP $20 \mathrm{mU}$.

$* * \mathrm{p}<0.01, * * * \mathrm{p}<0.005$ 


\section{In vitro mineralization}

In our mineralization model, the accumulation of HA deposits from osteoblast-like SaOS-2 cells was detected and quantitated by fluorescent staining. Fully phosphorylated OPN decreased the amount of produced HA by 67\% (Fig. 19). Dephosphorylation of OPN with TRAP gradually decreased the inhibitory effect of OPN the more phosphate that was cleaved off. Fully dephosphorylated OPN (i.e., -28 phosphates by TRAP), had no inhibitory effect on the mineralization process in this in vitro model (Fig. 19A). For BALP, removing 2 phosphates per mol OPN decreased the inhibitory capacity of OPN by approximately onethird to the same level as observed when removing 10 phosphates (Fig. 19B).

The inhibitory effect of OPN is dependent on the grade of phosphorylation of the OPN molecule. The results in paper IV show that both TRAP and BALP can dephosphorylate OPN and influence its inhibitory effect on mineralization, which suggests that both phosphatases have a role in the regulation of mineralization. TRAP is able to completely dephosphorylate OPN while BALP only partly dephosphorylates OPN. Several phosphorylations are implicated in the inhibitory action of OPN and some of these phosphorylations are rapidly liberated by either BALP or TRAP and seem to be controlling approximately $40-50 \%$ of the inhibitory effect. The remaining inhibition is among the last 18 phosphorylations and is only liberated by TRAP. This indicates that there are qualitative differences in the action of BALP and TRAP, which may have consequences for their functional roles in regulating mineralization. The assumptions that both TRAP and BALP can regulate the mineralization process are supported by the findings that TRAP displays enzymatic activity towards the known endogenous substrates for BALP, i.e., PPi and PLP. 

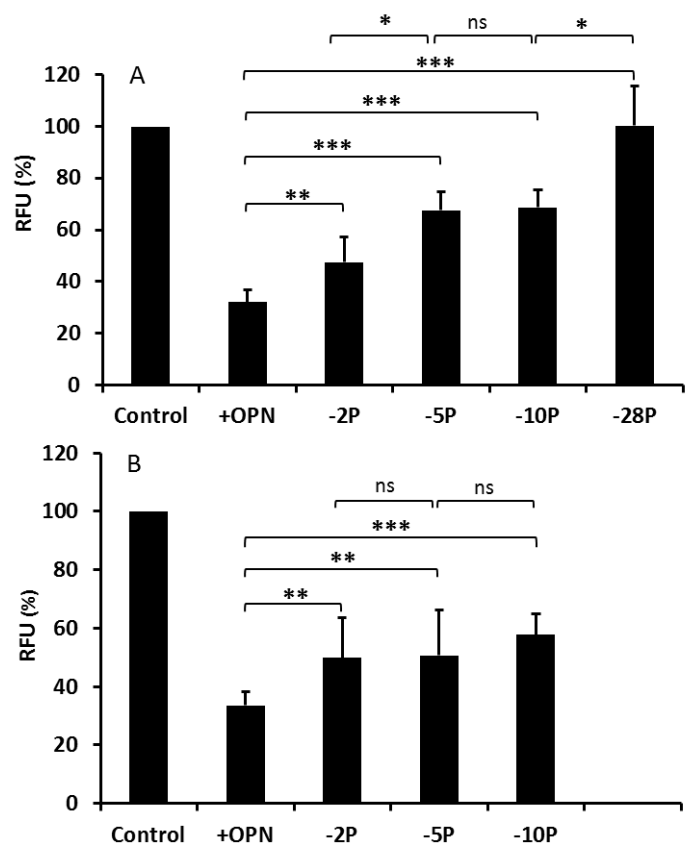

Figure 19. The amount of mineralization in osteoblast-like SaOS-2 cells 5 days after initiation of mineralization. Cells grown with mineralization medium but without OPN were defined as controls and considered to be fully mineralized, and set to $100 \%$ relative fluorescence units (RFU). The bars are expressed as percentages of $100 \%$ RFU. +OPN indicates the addition of OPN (fully phosphorylated), and $-2 \mathrm{P},-5 \mathrm{P},-10 \mathrm{P}$, and $-28 \mathrm{P}$ indicates the number of phosphates cleaved off (dephosphorylated OPN). OPN, fully phosphorylated and dephosphorylated, was added at a final concentration of $0.1 \mu \mathrm{g} / \mathrm{mL}$. Results are presented as mean \pm SD of three independent experiments with eight samples in each experiment.

A. OPN fully phosphorylated and dephosphorylated by TRAP. OPN was completely dephosphorylated by TRAP (-28P).

B. OPN fully phosphorylated and dephosphorylated by BALP.

$* \mathrm{p}<0.05, * * \mathrm{p}<0.01, * * * \mathrm{p}<0.005, \mathrm{~ns}=$ not significant. 


\section{Strengths and limitations of the thesis}

BALP isoforms from serum and bone tissue are difficult and time consuming to purify, separate and identify. There is only one commercially available BALP preparation (Calzyme Laboratories) on the market today that is purified from human bone and it is only partly purified. A limitation of the studies in paper I is that the BALP isoforms is purified from human osteoblast-like cells. Isoforms purified from human bone tissue or serum would have been preferable and a better reflection of BALP in vivo.

In paper II, the strength was the use of several different WT mouse strains to verify the absence of ALP activity in mouse liver. The results showing that WT mouse hepatocytes has insignificant amounts of TNALP mRNA and ALP activity, was demonstrated by histochemical staining, Northern and Western blot analysis, and activity-based assays. The presence of the BALP isoforms B/I, B1, B1x and B2 in mouse serum, from both WT and KO strains, was investigated and analyzed with a set of experiments, including heat inactivation, inhibitors, lectins, HPLC, and Q-Sepharose anion-exchange chromatography.

In paper III, the carefully designed SPR-based analysis allowed for quantification of binding differences between collagen type I and ALP isozymes and isoforms from various sources. A major strength in this study was the use of BALP preparations from two different origins, i.e., a partially purified commercially available BALP preparation from human bone tissue and a highly purified preparation from human osteoblast-like cells. The significant binding to collagen was demonstrated with BALP from both sources. Importantly, the results presented for the two BALP isoforms B1 and B2, which are commonly investigated as a single entity due to the complexities of separating them, confirmed the importance of glycosylations on the BALP molecule for collagen binding. A limitation of the study was the use of only one type of collagen, i.e., collagen type I, although this is the only collagen present in significant concentrations in bone matrix. The collagen used in this study was a commercially available native-like human collagen type I preparation purified from human neonatal fibroblasts, with a purity of $\geq 99.9 \%$ with no extracellular bone matrix compounds present that can interfere with the ALP-collagen binding. The collagen used does not self-assemble into collagen fibrils and have no cross-links present. 
The study in paper IV has a number of strengths, including the use of BALP extracted from human bone tissue. Previous studies investigating the inhibitory properties of OPN have applied excessive amounts of IALP to dephosphorylate OPN. IALP is a different isozyme than TNALP with approximately only 50\% sequence identity [76] and is not present in bone. Results from paper IV demonstrate that BALP and IALP differ significantly in their dephosphorylating properties. A further strength was the use of TNALP KO mice $\left(A l p \Gamma^{-\alpha}\right)$ and transgenic mice $\left(\mathrm{ColTg} ; \mathrm{Alpl}^{+/+}\right)$, in which the expression of TRAP was investigated for the first time. In addition, this study presents the first data on the inhibitory effect of OPN, dephosphorylated by TRAP, on in vitro mineralization of human osteoblast-like cells. The degree of phosphorylation for OPN varies with different sources and species. A limitation with this study is that we used OPN from bovine milk with 28 phosphorylation sites, which inhibited the mineralization by approximately $70 \%$. 


\section{CONCLUSIONS}

This thesis shows that:

PEA is not a substrate for BALP.

The BALP isoforms (i.e., B/I, B1x, B1 and B2) display different catalytic properties, which is attributed to their distinct $\mathrm{N}$-linked glycosylation patterns.

Mouse liver has undetectable amounts of ALP activity.

The genetic nomenclature for the Alpl gene in mice (i.e., ALP liver) should be reconsidered since mice have undetectable amounts of ALP in liver.

BALP and its isoforms B1 and B2, known to be involved in skeletal mineralization, binds significantly stronger to collagen type I in comparison with human ALPs expressed in non-mineralizing tissues.

Posttranslational glycosylation properties govern the binding interaction between BALP and collagen type I.

TRAP displays enzymatic activity towards the known endogenous substrates for BALP (i.e., PPi and PLP).

Both BALP and TRAP can reduce the inhibitory effect of OPN on mineralization by dephosphorylation. 


\section{FUTURE PERSPECTIVES}

To date, the different BALP isoforms can only be identified by HPLC. However, this particular HPLC assay is cumbersome and time consuming, and is therefore not suitable for routine analysis, or for BALP isoform analysis of samples from large cohorts. Further understanding of the molecular differences between these isoforms will facilitate the development of high-resolution diagnostic assays yielding a higher throughput of samples.

TNALP KO mice manifest defects in bone mineralization that mimic the phenotypic abnormalities of infantile HPP. Our studies of the BALP isoforms have demonstrated functional differences in kinetic properties and collagen binding abilities. The study by Wennberg et al. [167] demonstrated that media supplemented with recombinant human TNALP restored mineralization in osteoblast cultures from TNALP KO mice. Instead of using recombinant TNALP, we will supplement these cultures with purified BALP isoforms in an attempt to determine whether the ability to initiate calcification differs between these isoforms.

The functional aspects of the BALP isoforms will also be studied clinically in patients with HPP including genetic and clinical information about site-specific missense mutations of BALP in these patients. Mutations affecting the N-linked and O-linked oligosaccharide structures will be of particular interest.

The BALP isoform B1x has been found exclusively in serum from patients with chronic kidney disease, but not in serum from healthy individuals. These patients are more likely to develop vascular calcification and it is possible that the $\mathrm{B} 1 \mathrm{x}$ isoform is involved in the calcification process. Future studies should clarify the role of the BALP isoforms, in particular B1x, in vascular calcification. 


\section{ACKNOWLEDGEMENTS}

Many years have passed since I first started my work at Clinical Chemistry and many amazing people have crossed my path. In one way or another you have all helped me to achieve this goal and made the writing of this thesis possible.

First and foremost I would like to thank my supervisors:

Per Magnusson - my supervisor. Thank you for all support, encouragement, exceptional knowledge and friendship. Your enthusiasm and never ending quest to explore the mysteries of bone science is highly inspiring. "Only dead fish follow the stream".

Elvar Theodorsson - my assistant supervisor. Thank you for all help with statistical analysis and encouragement through the years. You have always been there to listen and give advice. All interesting conversations and laughs on the coffee breaks have lightened up many days.

Göran Andersson - my assistant supervisor. What you don't know about TRAP and OPN is not worth knowing. Thank you for all interesting and inspiring meetings at Karolinska. You have given me a broader perspective on bone remodeling.

I would also like to thank some of my co-authors. Without you this work would have been less enjoyable and of poorer quality.

José Luis Millán - a man with a contagious enthusiasm, an enormous energy and a lot of warmth. You always have an answer to my questions and an explanation to my findings. Thank you for good collaboration, fruitful discussions and all exiting ALP samples. I hope it doesn't stop here.

Sonoko Narisawa - The keeper of all the knockout mice. Your knowledge about the mice is outstanding and I appreciate and value all your hard work.

Karin Enander - The Master of the Biacore. I am so glad our paths have crossed again after all these years. Working with you has been both educating and fun. Let us hope for many more projects together.

Barbro Ek-Rylander - Kinetics are so much more understandable since I met you.

Maria Norgård - You are friend with TRAP, I am not. Thank you for all the work with TRAP and help in the lab. 
I am also thankful to:

Mathias Haarhaus - my big brother in science. I hope for more fun travels, more interesting discussions and to work more together in the future.

Anita Kullman - my wonderful roommate. We laugh, we cry and we solve the big problems in life. I miss not seeing you every week. The room is empty without you in so many ways.

Karolina Bäck - my colleague and friend. My cells would not have been as happy without you and my gels would still be slow. I value our friendship and all fun discussion about the important things in life.

Katrin Ivars- Thank you for all fun times and good laughs. The future is near my friend.

Martina Nylander - Always optimistic, encouraging and the holder of a big heart.

My work would have been so much less enjoyable without all friends, colleagues and students that has come and gone at Clinical Chemistry over the years. A special thanks to Sofia Ramström for thoughtful discussions about future, past and present, Kerstin Gustafsson for making everybody feel welcome, Kjersti Claesson for nice picture of fluorescent cells, Lars Faxälv for nice picture of not fluorescent cells, Martin Tellström for fixing everything and all other wonderful colleagues for making work a nice place to be at.

I am grateful to be a member of the Clinical Osteoporosis Research School (CORS) where I have met so many brilliant, inspiring researchers and new friends.

None of this would have been possible without the loving care and support from my family:

Ulla Britt Linder - my amazing mother and friend. Thank you for teaching me that everything is possible with hard work and that knowledge is the greatest gift of all. You always hold my back and are always there for me and my family whenever we need it.

Magnus Linder - my big brother that can fix everything. I am lucky to have a brother like you.

Anita and Kjell Halling - the best parents-in-law. You have saved us many times and your pre-cooked meal delivery are always much appreciated.

Last but not the least; I want to thank my wonderful family! You are my fantastic four. Gilbert, you are a part of this in so many ways. Thank you for cheerful and loving support and at least trying to understand what I do in the lab. You are my rock. My love. My best friend! Thank you for standing by my side.

Axel, Selma and Edith. You are the three stars in my life. Thank you for always keeping my feet on the ground and inspire me to be a better person. The sound of you laughter or the sight of your smiles make me forget everything else. Thank you for being you! 


\section{REFERENCES}

[1] Fantner G E, Hassenkam T, Kindt J H, Weaver J C, Birkedal H, Pechenik L, Cutroni J A, Cidade G A, Stucky G D, Morse D E, Hansma P K. (2005). Sacrificial bonds and hidden length dissipate energy as mineralized fibrils separate during bone fracture. Nat Mater 4, 612-616.

[2] Turner C H. (2006). Bone strength: current concepts. Ann N Y Acad Sci 1068, 429-446.

[3] Larsson L, Magnusson P. (2004) Metal Ions in Biological Systems. Chapter: Calcium status and supplementation. New York, NY, USA.: Marcel Dekker, Inc.

[4] Karsenty G. (2003). The complexities of skeletal biology. Nature 423, 316-318.

[5] Clarke B. (2008). Normal bone anatomy and physiology. Clin J Am Soc Nephrol 3 Suppl 3, 131-139.

[6] Foldes J, Parfitt A M, Shih M S, Rao D S, Kleerekoper M. (1991). Structural and geometric changes in iliac bone: relationship to normal aging and osteoporosis. J Bone Miner Res 6, 759-766.

[7] Roschger P, Paschalis E P, Fratzl P, Klaushofer K. (2008). Bone mineralization density distribution in health and disease. Bone 42, 456-466.

[8] Seeman E. (2002). Pathogenesis of bone fragility in women and men. Lancet 359, 1841-1850.

[9] Seeman E, Delmas P D. (2006). Bone quality--the material and structural basis of bone strength and fragility. N Engl J Med 354, 2250-2261.

[10] Boskey A L, Coleman R. (2010). Aging and bone. J Dent Res 89, 1333-1348.

[11] Riggs B L, Khosla S, Melton L J, 3rd. (1998). A unitary model for involutional osteoporosis: estrogen deficiency causes both type I and type II osteoporosis in postmenopausal women and contributes to bone loss in aging men. J Bone Miner Res 13, 763-773.

[12] Melton L J, 3rd, Atkinson E J, O'Connor M K, O'Fallon W M, Riggs B L. (1998). Bone density and fracture risk in men. J Bone Miner Res 13, 19151923.

[13] Manolagas S C. (2000). Birth and death of bone cells: basic regulatory mechanisms and implications for the pathogenesis and treatment of osteoporosis. Endocr Rev 21, 115-137.

[14] Burr D B. (2002). Targeted and nontargeted remodeling. Bone 30, 2-4.

[15] Parfitt A M. (2002). Targeted and nontargeted bone remodeling: relationship to basic multicellular unit origination and progression. Bone 30, 5-7.

[16] Crockett J C, Rogers M J, Coxon F P, Hocking L J, Helfrich M H. (2011). Bone remodelling at a glance. J Cell Sci 124, 991-998.

[17] Cardoso L, Herman B C, Verborgt O, Laudier D, Majeska R J, Schaffler M B. (2009). Osteocyte apoptosis controls activation of intracortical resorption in response to bone fatigue. J Bone Miner Res 24, 597-605.

[18] Mackie E J. (2003). Osteoblasts: novel roles in orchestration of skeletal architecture. Int J Biochem Cell Biol 35, 1301-1305. 
[19] Teitelbaum S L. (2007). Osteoclasts: what do they do and how do they do it? Am J Pathol 170, 427-435.

[20] Bonewald L F, Johnson M L. (2008). Osteocytes, mechanosensing and Wnt signaling. Bone 42, 606-615.

[21] Everts V, Delaisse J M, Korper W, Jansen D C, Tigchelaar-Gutter W, Saftig P, Beertsen W. (2002). The bone lining cell: its role in cleaning Howship's lacunae and initiating bone formation. J Bone Miner Res 17, 77-90.

[22] Andersen T L, Sondergaard T E, Skorzynska K E, Dagnaes-Hansen F, Plesner T L, Hauge E M, Plesner T, Delaisse J M. (2009). A physical mechanism for coupling bone resorption and formation in adult human bone. Am J Pathol 174, 239-247.

[23] Eriksen E F. (2010). Cellular mechanisms of bone remodeling. Rev Endocr Metab Disord 11, 219-227.

[24] Agerbaek M O, Eriksen E F, Kragstrup J, Mosekilde L, Melsen F. (1991). A reconstruction of the remodelling cycle in normal human cortical iliac bone. Bone Miner 12, 101-112.

[25] Eriksen E F, Gundersen H J, Melsen F, Mosekilde L. (1984). Reconstruction of the formative site in iliac trabecular bone in 20 normal individuals employing a kinetic model for matrix and mineral apposition. Metab Bone Dis Relat Res 5, 243-252.

[26] Eriksen E F, Melsen F, Mosekilde L. (1984). Reconstruction of the resorptive site in iliac trabecular bone: a kinetic model for bone resorption in 20 normal individuals. Metab Bone Dis Relat Res 5, 235-242.

[27] Riggs B L, Parfitt A M. (2005). Drugs used to treat osteoporosis: the critical need for a uniform nomenclature based on their action on bone remodeling. $\mathrm{J}$ Bone Miner Res 20, 177-184.

[28] Gilbert L, He X, Farmer P, Rubin J, Drissi H, van Wijnen A J, Lian J B, Stein G S, Nanes M S. (2002). Expression of the osteoblast differentiation factor RUNX2 (Cbfa1/AML3/Pebp2alpha A) is inhibited by tumor necrosis factoralpha. J Biol Chem 277, 2695-2701.

[29] Komori T, Yagi H, Nomura S, Yamaguchi A, Sasaki K, Deguchi K, Shimizu Y, Bronson R T, Gao Y H, Inada M, Sato M, Okamoto R, Kitamura Y, Yoshiki S, Kishimoto T. (1997). Targeted disruption of Cbfa1 results in a complete lack of bone formation owing to maturational arrest of osteoblasts. Cell 89, 755-764.

[30] Capulli M, Paone R, Rucci N. (2014). Osteoblast and osteocyte: games without frontiers. Arch Biochem Biophys 561, 3-12.

[31] Murshed M, Harmey D, Millan J L, McKee M D, Karsenty G. (2005). Unique coexpression in osteoblasts of broadly expressed genes accounts for the spatial restriction of ECM mineralization to bone. Genes Dev 19, 1093-1104.

[32] Bonewald L F. (2011). The amazing osteocyte. J Bone Miner Res 26, 229-238.

[33] Jilka R L, Weinstein R S, Bellido T, Parfitt A M, Manolagas S C. (1998). Osteoblast programmed cell death (apoptosis): modulation by growth factors and cytokines. J Bone Miner Res 13, 793-802.

[34] Franz-Odendaal T A, Hall B K, Witten P E. (2006). Buried alive: how osteoblasts become osteocytes. Dev Dyn 235, 176-190.

[35] Holmbeck K, Bianco P, Pidoux I, Inoue S, Billinghurst R C, Wu W, Chrysovergis K, Yamada S, Birkedal-Hansen H, Poole A R. (2005). The metalloproteinase MT1-MMP is required for normal development and maintenance of osteocyte processes in bone. J Cell Sci 118, 147-156. 
[36] Dallas S L, Prideaux M, Bonewald L F. (2013). The osteocyte: an endocrine cell ... and more. Endocr Rev 34, 658-690.

[37] Piper K, Boyde A, Jones S J. (1992). The relationship between the number of nuclei of an osteoclast and its resorptive capability in vitro. Anat Embryol 186, 291-299.

[38] Suda T, Takahashi N, Martin T J. (1992). Modulation of osteoclast differentiation. Endocr Rev 13, 66-80.

[39] Boyle W J, Simonet W S, Lacey D L. (2003). Osteoclast differentiation and activation. Nature 423, 337-342.

[40] Kanehisa J, Heersche J N. (1988). Osteoclastic bone resorption: in vitro analysis of the rate of resorption and migration of individual osteoclasts. Bone 9, 73-79.

[41] Väänänen H K, Horton M. (1995). The osteoclast clear zone is a specialized cell-extracellular matrix adhesion structure. J Cell Sci 108 2729-2732.

[42] Blair H C, Teitelbaum S L, Ghiselli R, Gluck S. (1989). Osteoclastic bone resorption by a polarized vacuolar proton pump. Science 245, 855-857.

[43] Väänänen H K, Karhukorpi E K, Sundquist K, Wallmark B, Roininen I, Hentunen T, Tuukkanen J, Lakkakorpi P. (1990). Evidence for the presence of a proton pump of the vacuolar $\mathrm{H}(+)$-ATPase type in the ruffled borders of osteoclasts. J Cell Biol 111, 1305-1311.

[44] Väänänen H K, Zhao H, Mulari M, Halleen J M. (2000). The cell biology of osteoclast function. J Cell Sci 113, 377-381.

[45] Gowen M, Lazner F, Dodds R, Kapadia R, Feild J, Tavaria M, Bertoncello I, Drake F, Zavarselk S, Tellis I, Hertzog P, Debouck C, Kola I. (1999). Cathepsin $\mathrm{K}$ knockout mice develop osteopetrosis due to a deficit in matrix degradation but not demineralization. J Bone Miner Res 14, 1654-1663.

[46] Silver F H, Freeman J W, Seehra G P. (2003). Collagen self-assembly and the development of tendon mechanical properties. J Biomech 36, 1529-1553.

[47] Garnero P. (2015). The Role of Collagen Organization on the Properties of Bone. Calcif Tissue Int 97, 229-240.

[48] Shoulders M D, Raines R T. (2009). Collagen structure and stability. Annu Rev Biochem 78, 929-958.

[49] Rauch F, Travers R, Parfitt A M, Glorieux F H. (2000). Static and dynamic bone histomorphometry in children with osteogenesis imperfecta. Bone 26, 581-589.

[50] Xiao J, Cheng H, Silva T, Baum J, Brodsky B. (2011). Osteogenesis imperfecta missense mutations in collagen: structural consequences of a glycine to alanine replacement at a highly charged site. Biochemistry 50, 10771-10780.

[51] Stein G S, Lian J B, Stein J L, Van Wijnen A J, Montecino M. (1996). Transcriptional control of osteoblast growth and differentiation. Physiol Rev. 76, 593-629.

[52] Bala Y, Farlay D, Delmas P D, Meunier P J, Boivin G. (2010). Time sequence of secondary mineralization and microhardness in cortical and cancellous bone from ewes. Bone 46, 1204-1212.

[53] Bala Y, Seeman E. (2015). Bone's Material Constituents and their Contribution to Bone Strength in Health, Disease, and Treatment. Calcif Tissue Int 97, 308326.

[54] Shapiro I M, Landis W J, Risbud M V. (2015). Matrix vesicles: Are they anchored exosomes? Bone 79, 29-36. 
[55] Ali S Y, Sajdera S W, Anderson H C. (1970). Isolation and characterization of calcifying matrix vesicles from epiphyseal cartilage. Proc Natl Acad Sci U S A 67, 1513-1520.

[56] Anderson H C, Hsu H H, Morris D C, Fedde K N, Whyte M P. (1997). Matrix vesicles in osteomalacic hypophosphatasia bone contain apatite-like mineral crystals. Am J Pathol 151, 1555-1561.

[57] Boskey A L, Boyan B D, Schwartz Z. (1997). Matrix vesicles promote mineralization in a gelatin gel. Calcif Tissue Int 60, 309-315.

[58] Wu L N, Genge B R, Lloyd G C, Wuthier R E. (1991). Collagen-binding proteins in collagenase-released matrix vesicles from cartilage. Interaction between matrix vesicle proteins and different types of collagen. J Biol Chem 266, 1195-1203.

[59] Millan J L. (2013). The role of phosphatases in the initiation of skeletal mineralization. Calcif Tissue Int 93, 299-306.

[60] Golub E E. (2009). Role of matrix vesicles in biomineralization. Biochim Biophys Acta 1790, 1592-1598.

[61] Anderson H C, Garimella R, Tague S E. (2005). The role of matrix vesicles in growth plate development and biomineralization. Front Biosci 10, 822-837.

[62] McKee M D, Hoac B, Addison W N, Barros N M, Millan J L, Chaussain C. (2013). Extracellular matrix mineralization in periodontal tissues:

Noncollagenous matrix proteins, enzymes, and relationship to hypophosphatasia and X-linked hypophosphatemia. Periodontology 200063 , 102-122.

[63] Vittur F, Stagni N, Moro L, de Bernard B. (1984). Alkaline phosphatase binds to collagen; a hypothesis on the mechanism of extravesicular mineralization in epiphyseal cartilage. Experientia 40, 836-837.

[64] Wu L N, Genge B R, Wuthier R E. (1992). Evidence for specific interaction between matrix vesicle proteins and the connective tissue matrix. Bone Miner 17, 247-252.

[65] Millán J L, Whyte M P. (2016). Alkaline phosphatase and hypophosphatasia. Calcif Tissue Int, (In press).

[66] McComb R B, Bowers Jr G N, Posen S. (1979) Alkaline phosphatase. New York, NY, USA: Plenum Press.

[67] Suzuki U, Yoshimura K, Takaishi M. (1907). Ueber ein enzyme "phytase" das "anhydro-oxy-methylen diphosphorsäure" spaltet. Bull Coll Agric Tokyo Imp Univ 7, 503-512.

[68] Plimmer R H. (1913). The metabolism of organic phosphorus compounds. Their hydrolysis by the action of enzymes. Biochem J 7, 43-71.

[69] Robison R. (1923). The possible significance of hexosephosphoric esters in ossification. Biochem J 17, 286-293.

[70] Robison R. (1991). The classic: The possible significance of hexosephosphoric esters in ossification. Clin Orthop 267, 2-7.

[71] Robison R, Soames K M. (1924). The possible significance of hexosephosphoric esters in ossification: Part II. The phosphoric esterase of ossifying cartilage. Biochem J 18, 740-754.

[72] Rathbun J C. (1948). Hypophosphatasia; a new developmental anomaly. Am J Dis Child 75, 822-831.

[73] Schwartz J H, Lipmann F. (1961). Phosphate incorporation into alkaline phosphatase of E. coli. Proc Natl Acad Sci U S A 47, 1996-2005. 
[74] Hull W E, Halford S E, Gutfreund H, Sykes B D. (1976). 31P nuclear magnetic resonance study of alkaline phosphatase: the role of inorganic phosphate in limiting the enzyme turnover rate at alkaline pH. Biochemistry 15, 1547-1561.

[75] Weiss M J, Ray K, Henthorn P S, Lamb B, Kadesch T, Harris H. (1988). Structure of the human liver/bone/kidney alkaline phosphatase gene. J Biol Chem 263, 12002-12010.

[76] Millán J L. (2006) Mammalian alkaline phosphatase. From biology to applications in medicine and biotechnology. Weinheim, Germany: WILEYVCH Verlag GmgH \& Co. KGaA.

[77] Magnusson P, Degerblad M, Sääf M, Larsson L, Thorén M. (1997). Different responses of bone alkaline phosphatase isoforms during recombinant insulinlike growth factor-I (IGF-I) and during growth hormone therapy in adults with growth hormone deficiency. J Bone Miner Res 12, 210-220.

[78] Martin D, Tucker D F, Gorman P, Sheer D, Spurr N K, Trowsdale J. (1987). The human placental alkaline phosphatase gene and related sequences map to chromosome 2 band q37. Ann Hum Genet 51, 145-152.

[79] Smith M, Weiss M J, Griffin C A, Murray J C, Buetow K H, Emanuel B S, Henthorn P S, Harris H. (1988). Regional assignment of the gene for human liver/bone/kidney alkaline phosphatase to chromosome 1p36.1-p34. Genomics 2, 139-143.

[80] Harris H. (1990). The human alkaline phosphatases: what we know and what we don't know. Clin Chim Acta 186, 133-150.

[81] Swallow D M, Povey S, Parkar M, Andrews P W, Harris H, Pym B, Goodfellow P. (1986). Mapping of the gene coding for the human liver/bone/kidney isozyme of alkaline phosphatase to chromosome 1. Ann Hum Genet 50, 229-235.

[82] Nosjean O, Koyama I, Goseki M, Roux B, Komoda T. (1997). Human tissue non-specific alkaline phosphatases: sugar-moiety-induced enzymic and antigenic modulations and genetic aspects. Biochem J 321, 297-303.

[83] Magnusson P, Farley J R. (2002). Differences in sialic acid residues among bone alkaline phosphatase isoforms: a physical, biochemical, and immunological characterization. Calcif Tissue Int 71, 508-518.

[84] Halling Linder C, Narisawa S, Millán J L, Magnusson P. (2009). Glycosylation differences contribute to distinct catalytic properties among bone alkaline phosphatase isoforms. Bone 45, 987-993.

[85] Fishman L, Miyayama H, Driscoll S G, Fishman W H. (1976). Developmental phase-specific alkaline phosphatase isoenzymes of human placenta and thier occurrence in human cancer. Cancer Res 36, 2268-2273.

[86] Narisawa S, Hasegawa H, Watanabe K, Millan J L. (1994). Stage-specific expression of alkaline phosphatase during neural development in the mouse. Dev Dyn 201, 227-235.

[87] Hahnel A C, Rappolee D A, Millán J L, Manes T, Ziomek C A, Theodosiou N G, Werb Z, Pedersen R A, Schultz G A. (1990). Two alkaline phosphatase genes are expressed during early development in the mouse embryo. Development 110, 555-564.

[88] Narisawa S, Fröhlander N, Millán J L. (1997). Inactivation of two mouse alkaline phosphatase genes and establishment of a model of infantile hypophosphatasia. Dev Dyn 208, 432-446. 
[89] Manes T, Glade K, Ziomek C A, Millán J L. (1990). Genomic structure and comparison of mouse tissue-specific alkaline phosphatase genes. Genomics 8, 541-554.

[90] Waymire K G, Mahuren J D, Jaje J M, Guilarte T R, Coburn S P, MacGregor G R. (1995). Mice lacking tissue non-specific alkaline phosphatase die from seizures due to defective metabolism of vitamin B-6. Nat Genet 11, 45-51.

[91] Kim E E, Wyckoff H W. (1991). Reaction mechanism of alkaline phosphatase based on crystal structures. Two-metal ion catalysis. J Mol Biol 218, 449-464.

[92] Sowadski J M, Handschumacher M D, Murthy H M, Kundrot C E, Wyckoff H W. (1983). Crystallographic observations of the metal ion triple in the active site region of alkaline phosphatase. J Mol Biol 170, 575-581.

[93] Wyckoff H W, Handschumacher M, Murthy H M, Sowadski J M. (1983). The three dimensional structure of alkaline phosphatase from E. coli. Adv Enzymol Relat Areas Mol Biol 55, 453-480.

[94] Coleman J E. (1992). Structure and mechanism of alkaline phosphatase. Annu Rev Biophys Biomol Struct 21, 441-483.

[95] Le Du M H, Stigbrand T, Taussig M J, Menez A, Stura E A. (2001). Crystal structure of alkaline phosphatase from human placenta at $1.8 \mathrm{~A}$ resolution. Implication for a substrate specificity. J Biol Chem 276, 9158-9165.

[96] Murphy J E, Tibbitts T T, Kantrowitz E R. (1995). Mutations at positions 153 and 328 in Escherichia coli alkaline phosphatase provide insight towards the structure and function of mammalian and yeast alkaline phosphatases. $\mathrm{J}$ Mol Biol 253, 604-617.

[97] Le Du M H, Millan J L. (2002). Structural evidence of functional divergence in human alkaline phosphatases. J Biol Chem 277, 49808-49814.

[98] Hummer C, Millan J L. (1991). Gly429 is the major determinant of uncompetitive inhibition of human germ cell alkaline phosphatase by L-leucine. Biochem J 274 (Pt 1), 91-95.

[99] Hoylaerts M F, Manes T, Millan J L. (1997). Mammalian alkaline phosphatases are allosteric enzymes. J Biol Chem 272, 22781-22787.

[100] Hoylaerts M F, Ding L, Narisawa S, Van Kerckhoven S, Millan J L. (2006). Mammalian alkaline phosphatase catalysis requires active site structure stabilization via the $\mathrm{N}$-terminal amino acid microenvironment. Biochemistry 45, 9756-9766.

[101] Tsonis P A, Argraves W S, Millan J L. (1988). A putative functional domain of human placental alkaline phosphatase predicted from sequence comparisons. Biochem J 254, 623-624.

[102] Bossi M, Hoylaerts M F, Millan J L. (1993). Modifications in a flexible surface loop modulate the isozyme-specific properties of mammalian alkaline phosphatases. J Biol Chem 268, 25409-25416.

[103] Hoylaerts M F, Manes T, Millan J L. (1992). Molecular mechanism of uncompetitive inhibition of human placental and germ-cell alkaline phosphatase. Biochem J 286, 23-30.

[104] Mornet E, Stura E, Lia-Baldini A S, Stigbrand T, Menez A, Le Du M H. (2001). Structural evidence for a functional role of human tissue nonspecific alkaline phosphatase in bone mineralization. J Biol Chem 276, 31171-31178.

[105] Magnusson P, Ärlestig L, Paus E, Di Mauro S, Testa M P, Stigbrand T, Farley J R, Nustad K, Millán J L. (2002). Monoclonal antibodies against tissuenonspecific alkaline phosphatase. Report of the ISOBM TD9 workshop. Tumour Biol 23, 228-248. 
[106] Morris D C, Masuhara K, Takaoka K, Ono K, Anderson H C. (1992). Immunolocalization of alkaline phosphatase in osteoblasts and matrix vesicles of human fetal bone. Bone Miner 19, 287-298.

[107] Nosjean O, Briolay A, Roux B. (1997). Mammalian GPI proteins: sorting, membrane residence and functions. Biochim Biophys Acta 1331, 153-186.

[108] Davitz M A, Hereld D, Shak S, Krakow J, Englund P T, Nussenzweig V. (1987). A glycan-phosphatidylinositol-specific phospholipase D in human serum. Science 238, 81-84.

[109] Low M G. (1988). Glycosylphosphatidylinositol: an anchor for eukaryotic membrane proteins. Biochem Soc Trans 16, 271-272.

[110] Anh D J, Eden A, Farley J R. (2001). Quantitation of soluble and skeletal alkaline phosphatase, and insoluble alkaline phosphatase anchor-hydrolase activities in human serum. Clin Chim Acta 311, 137-148.

[111] Magnusson P, Sharp C A, Magnusson M, Risteli J, Davie M W, Larsson L. (2001). Effect of chronic renal failure on bone turnover and bone alkaline phosphatase isoforms. Kidney Int 60, 257-265.

[112] Haarhaus M, Fernström A, Magnusson M, Magnusson P. (2009). Clinical significance of bone alkaline phosphatase isoforms, including the novel B1x isoform, in mild to moderate chronic kidney disease. Nephrol Dial Transplant 24, 3382-3389.

[113] Magnusson P, Sharp C A, Farley J R. (2002). Different distributions of human bone alkaline phosphatase isoforms in serum and bone tissue extracts. Clin Chim Acta 325, 59-70.

[114] Sardiwal S, Magnusson P, Goldsmith D J, Lamb E J. (2013). Bone alkaline phosphatase in CKD-mineral bone disorder. Am J Kidney Dis 62, 810-822.

[115] Magnusson P, Larsson L, Magnusson M, Davie M W, Sharp C A. (1999). Isoforms of bone alkaline phosphatase: characterization and origin in human trabecular and cortical bone. J Bone Miner Res 14, 1926-1933.

[116] Weiss M J, Cole D E, Ray K, Whyte M P, Lafferty M A, Mulivor R A, Harris H. (1988). A missense mutation in the human liver/bone/kidney alkaline phosphatase gene causing a lethal form of hypophosphatasia. Proc Natl Acad Sci U S A 85, 7666-7669.

[117] Whyte M P. (1994). Hypophosphatasia and the role of alkaline phosphatase in skeletal mineralization. Endocr Rev 15, 439-461.

[118] Whyte M P, Zhang F, Wenkert D, McAlister W H, Mack K E, Benigno M C, Coburn S P, Wagy S, Griffin D M, Ericson K L, Mumm S. (2015). Hypophosphatasia: validation and expansion of the clinical nosology for children from 25 years experience with 173 pediatric patients. Bone 75, 229239.

[119] Mornet E, Nunes M E. (1993) Hypophosphatasia, GeneReviews (www.ncbi.nlm.nih.gov/books/NBK1150/). Seattle, WA, USA: University of Washington.

[120] Fedde K N, Blair L, Silverstein J, Coburn S P, Ryan L M, Weinstein R S, Waymire K, Narisawa S, Millán J L, MacGregor G R, Whyte M P. (1999). Alkaline phosphatase knock-out mice recapitulate the metabolic and skeletal defects of infantile hypophosphatasia. J Bone Miner Res 14, 2015-2026.

[121] Harmey D, Hessle L, Narisawa S, Johnson K A, Terkeltaub R, Millán J L. (2004). Concerted regulation of inorganic pyrophosphate and osteopontin by akp2, enpp1, and ank: an integrated model of the pathogenesis of mineralization disorders. Am J Pathol 164, 1199-1209. 
[122] Hessle L, Johnson K A, Anderson H C, Narisawa S, Sali A, Goding J W, Terkeltaub R, Millán J L. (2002). Tissue-nonspecific alkaline phosphatase and plasma cell membrane glycoprotein-1 are central antagonistic regulators of bone mineralization. Proc Natl Acad Sci U S A 99, 9445-9449.

[123] Whyte M P, Landt M, Ryan L M, Mulivor R A, Henthorn P S, Fedde K N, Mahuren J D, Coburn S P. (1995). Alkaline phosphatase: placental and tissuenonspecific isoenzymes hydrolyze phosphoethanolamine, inorganic pyrophosphate, and pyridoxal 5'-phosphate. Substrate accumulation in carriers of hypophosphatasia corrects during pregnancy. J Clin Invest 95, 1440-1445.

[124] Whyte M P, Mahuren J D, Vrabel L A, Coburn S P. (1985). Markedly increased circulating pyridoxal-5'-phosphate levels in hypophosphatasia. Alkaline phosphatase acts in vitamin B6 metabolism. J Clin Invest 76, 752-756.

[125] Baumgartner-Sigl S, Haberlandt E, Mumm S, Scholl-Burgi S, Sergi C, Ryan L, Ericson K L, Whyte M P, Hogler W. (2007). Pyridoxine-responsive seizures as the first symptom of infantile hypophosphatasia caused by two novel missense mutations (c.677T >C, p.M226T; c.1112C>T, p.T371I) of the tissue-nonspecific alkaline phosphatase gene. Bone 40, 1655-1661.

[126] Hanics J, Barna J, Xiao J, Millan J L, Fonta C, Negyessy L. (2012). Ablation of TNAP function compromises myelination and synaptogenesis in the mouse brain. Cell Tissue Res 349, 459-471.

[127] Buchet R, Millán J L, Magne D. (2013). Multisystemic functions of alkaline phosphatases. Methods Mol Biol 1053, 27-51.

[128] Carr S A, Huddleston M J, Bean M F. (1993). Selective identification and differentiation of $\mathrm{N}$ - and O-linked oligosaccharides in glycoproteins by liquid chromatography-mass spectrometry. Protein Sci 2, 183-196.

[129] Schwarz F, Aebi M. (2011). Mechanisms and principles of N-linked protein glycosylation. Curr Opin Struct Biol 21, 576-582.

[130] Schachter H. (2000). The joys of HexNAc. The synthesis and function of Nand O-glycan branches. Glycoconj J 17, 465-483.

[131] Durand G, Seta N. (2000). Protein glycosylation and diseases: blood and urinary oligosaccharides as markers for diagnosis and therapeutic monitoring. Clin Chem 46, 795-805.

[132] Ohtsubo K, Marth J D. (2006). Glycosylation in cellular mechanisms of health and disease. Cell 126, 855-867.

[133] Weiss M J, Henthorn P S, Lafferty M A, Slaughter C, Raducha M, Harris H. (1986). Isolation and characterization of a cDNA encoding a human liver/bone/kidney-type alkaline phosphatase. Proc Natl Acad Sci U S A 83, 7182-7186.

[134] Komaru K, Satou Y, Al-Shawafi H A, Numa-Kinjoh N, Sohda M, Oda K. (2016). Glycosylation-deficient mutations in tissue-nonspecific alkaline phosphatase impair its structure and function and are linked to infantile hypophosphatasia. FEBS J.

[135] Watanabe T, Wada N, Chou J Y. (1992). Structural and functional analysis of human germ cell alkaline phosphatase by site-specific mutagenesis. Biochemistry 31, 3051-3058.

[136] Farley J R, Kyeyune-Nyombi E, Tarbaux N M, Hall S L, Strong D D. (1989). Alkaline phosphatase activity from human osteosarcoma cell line SaOS-2: an isoenzyme standard for quantifying skeletal alkaline phosphatase activity in serum. Clin Chem 35, 223-229. 
[137] Farley J R, Hall S L, Herring S, Tarbaux N M, Matsuyama T, Wergedal J E. (1991). Skeletal alkaline phosphatase specific activity is an index of the osteoblastic phenotype in subpopulations of the human osteosarcoma cell line SaOS-2. Metabolism 40, 664-671.

[138] Rodan S B, Imai Y, Thiede M A, Wesolowski G, Thompson D, Bar-Shavit Z, Shull S, Mann K, Rodan G A. (1987). Characterization of a human osteosarcoma cell line (Saos-2) with osteoblastic properties. Cancer Res 47, 4961-4966.

[139] Murray E, Provvedini D, Curran D, Catherwood B, Sussman H, Manolagas S. (1987). Characterization of a human osteoblastic osteosarcoma cell line (SAOS2) with high bone alkaline phosphatase activity. J Bone Miner Res 2, 231-238.

[140] Hooper N M. (1997). Glycosyl-phosphatidylinositol anchored membrane enzymes. Clin Chim Acta 266, 3-12.

[141] Fedde K N, Lane C C, Whyte M P. (1988). Alkaline phosphatase is an ectoenzyme that acts on micromolar concentrations of natural substrates at physiologic $\mathrm{pH}$ in human osteosarcoma (SAOS-2) cells. Arch Biochem Biophys 264, 400-409.

[142] Di Mauro S, Manes T, Hessle L, Kozlenkov A, Pizauro J M, Hoylaerts M F, Millán J L. (2002). Kinetic characterization of hypophosphatasia mutations with physiological substrates. J Bone Miner Res 17, 1383-1391.

[143] Millán J L, Narisawa S, Lemire I, Loisel T P, Boileau G, Leonard P, Gramatikova S, Terkeltaub R, Pleshko Camacho N, McKee M D, Crine P, Whyte M P. (2008). Enzyme replacement therapy for murine hypophosphatasia. J Bone Miner Res 23, 777-787.

[144] Rea D W, Ultee M E, Chen S X, Loisel T P. (2008). Solutions for purification of Fc-fusion proteins BioPharm Int (March Suppl), 20-25.

[145] Whyte M P, Greenberg C R, Salman N J, Bober M B, McAlister W H, Wenkert D, Van Sickle B J, Simmons J H, Edgar T S, Bauer M L, Hamdan M A, Bishop N, Lutz R E, McGinn M, Craig S, Moore J N, Taylor J W, Cleveland R H, Cranley W R, Lim R, Thacher T D, Mayhew J E, Downs M, Millan J L, Skrinar A M, Crine P, Landy H. (2012). Enzyme-replacement therapy in lifethreatening hypophosphatasia. New Engl J Med 366, 904-913.

[146] Krumpel M, Reithmeier A, Senge T, Baeumler T A, Frank M, Nyholm P G, EkRylander B, Andersson G. (2015). The small chemical enzyme inhibitor 5phenylnicotinic acid/CD13 inhibits cell migration and invasion of tartrateresistant acid phosphatase/ACP5-overexpressing MDA-MB-231 breast cancer cells. Exp Cell Res 339, 154-162.

[147] Bayless K J, Davis G E, Meininger G A. (1997). Isolation and biological properties of osteopontin from bovine milk. Protein Expr Purif 9, 309-314.

[148] Ljusberg J, Ek-Rylander B, Andersson G. (1999). Tartrate-resistant purple acid phosphatase is synthesized as a latent proenzyme and activated by cysteine proteinases. Biochem J 343 63-69.

[149] Narisawa S, Yadav M C, Millán J L. (2013). In vivo overexpression of tissuenonspecific alkaline phosphatase increases skeletal mineralization and affects the phosphorylation status of osteopontin. J Bone Miner Res 28, 1587-1598.

[150] Magnusson P, Löfman O, Larsson L. (1993). Methodological aspects on separation and reaction conditions of bone and liver alkaline phosphatase isoform analysis by high-performance liquid chromatography. Anal Biochem 211, 156-163. 
[151] Magnusson P, Löfman O, Larsson L. (1992). Determination of alkaline phosphatase isoenzymes in serum by high-performance liquid chromatography with post-column reaction detection. J Chromatogr 576, 79-86.

[152] Sharp C A, Linder C, Magnusson P. (2007). Analysis of human bone alkaline phosphatase isoforms: comparison of isoelectric focusing and ion-exchange high-performance liquid chromatography. Clin Chim Acta 379, 105-112.

[153] Smith P K, Krohn R I, Hermanson G T, Mallia A K, Gartner F H, Provenzano M D, Fujimoto E K, Goeke N M, Olson B J, Klenk D C. (1985). Measurement of protein using bicinchoninic acid. Anal Biochem 150, 76-85.

[154] Liedberg B, Nylander C, Lunström I. (1983). Surface plasmon resonance for gas detection and biosensing. Sens Actuators 4, 299-304.

[155] Enander K. (2003). Folded polypeptide scaffolds for biosensor and biochip applications-design, synthesis, functionalisation and characterisation. Linköping University, Linköping Studies in Science and Technology, Dissertation No. 848.

[156] Heinonen J K, Lahti R J. (1981). A new and convenient colorimetric determination of inorganic orthophosphate and its application to the assay of inorganic pyrophosphatase. Anal Biochem 113, 313-317.

[157] Narisawa S, Hoylaerts M F, Doctor K S, Fukuda M N, Alpers D H, Millan J L. (2007). A novel phosphatase upregulated in Akp3 knockout mice. Am J Physiol Gastrointest Liver Physiol 293, 1068-1077.

[158] Ek-Rylander B, Barkhem T, Ljusberg J, Ohman L, Andersson K K, Andersson G. (1997). Comparative studies of rat recombinant purple acid phosphatase and bone tartrate-resistant acid phosphatase. Biochem J 321, 305-311.

[159] Wang Y H, Liu Y, Maye P, Rowe D W. (2006). Examination of mineralized nodule formation in living osteoblastic cultures using fluorescent dyes. Biotechnol Prog 22, 1697-1701.

[160] Bonewald L F, Harris S E, Rosser J, Dallas M R, Dallas S L, Camacho N P, Boyan B, Boskey A. (2003). von Kossa staining alone is not sufficient to confirm that mineralization in vitro represents bone formation. Calcif Tissue Int 72, 537-547.

[161] Fedde K N, Whyte M P. (1990). Alkaline phosphatase (tissue-nonspecific isoenzyme) is a phosphoethanolamine and pyridoxal-5'-phosphate ectophosphatase: normal and hypophosphatasia fibroblast study. Am J Hum Genet 47, 767-775.

[162] Millán J L, Whyte M P, Avioli L V, Fishman W H. (1980). Hypophosphatasia (adult form): quantitation of serum alkaline phosphatase isoenzyme activity in a large kindred. Clin Chem 26, 840-845.

[163] Roberts S J, Stewart A J, Sadler P J, Farquharson C. (2004). Human PHOSPHO1 exhibits high specific phosphoethanolamine and phosphocholine phosphatase activities. Biochem J 382, 59-65.

[164] Fleshood H L, Pitot H C. (1970). The metabolism of Ophosphorylethanolamine in animal tissues. I. O-phosphorylethanolamine phospho-lyase: partial purification and characterization. J Biol Chem 245, 4414-4420.

[165] Price P A, Toroian D, Chan W S. (2009). Tissue-nonspecific alkaline phosphatase is required for the calcification of collagen in serum: a possible mechanism for biomineralization. J Biol Chem 284, 4594-4604. 
[166] Sorensen E S, Hojrup P, Petersen T E. (1995). Posttranslational modifications of bovine osteopontin: identification of twenty-eight phosphorylation and three O-glycosylation sites. Protein Sci 4, 2040-2049.

[167] Wennberg C, Hessle L, Lundberg P, Mauro S, Narisawa S, Lerner U H, Millán J L. (2000). Functional characterization of osteoblasts and osteoclasts from alkaline phosphatase knockout mice. J Bone Miner Res 15, 1879-1888. 


\section{Papers}

The articles associated with this thesis have been removed for copyright reasons. For more details about these see:

http://urn.kb.se/resolve?urn=urn:nbn:se:liu:diva-127100 